\title{
Comparação de protocolos de extração de DNA para detecção de Mycobacterium bovis através da PCR em homogeneizados de órgãos bovinos
}

Dissertação apresentada ao Programa de Pós-Graduação em Epidemiologia Experimental e Aplicada às Zoonoses da Faculdade de Medicina Veterinária e Zootecnia da Universidade de São Paulo para obtenção do título de Mestre em Medicina Veterinária

\section{Departamento:}

Medicina Veterinária Preventiva e Saúde Animal

Área de concentração:

Epidemiologia Experimental e Aplicada às Zoonoses

\section{Orientador:}

Prof. Dr. José Soares Ferreira Neto

São Paulo 


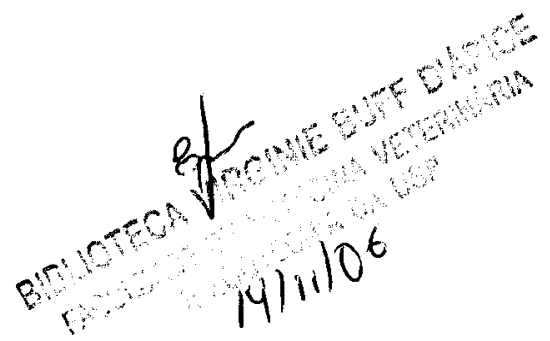

\section{DADOS INTERNACIONAIS DE CATALOGAÇÃO-NA-PUBLICAÇÃO}

(Biblioteca Virginie Buff D'Ápice da Faculdade de Medicina Veterinária e Zootecnia da Universidade de Sāo Paulo)

T.1788

FMVZ

\section{Ribeiro, Daniella Carvalho}

Comparaçào de protocolos de extraçào de DNA para detecçào de Mycobacterium bovis através da PCR em homogeneizados de órgàos bovinos. / Daniella Carvalho Ribeiro. - Sào Paulo: D. C. Ribeiro. 2006.

$$
55 \mathrm{f} \text { : : il. }
$$

Dissertação (mestraço) - Universidade de Sào Paulo. Faculdade de Medicina Veterinária e Zootecnia. Departamento de Medicina Veterinária Preventiva e Saúde Animal, 2006.

Programa de Pós-Graduaçào: Epidemiologia Experimental e Aplicada às Zoonoses.

Área de concentraçào: Epidemiologia Experimental e Aplicada às Zoonoses.

Orientador: Prof. Dr. José Soares Ferreira Neto.

1. Mycobacterium bovis. 2. Bovinos. 3. DNA (extraçào). 4. Reaçào em cadeia por polimerase. 5. Linfonodos de animal.. I. Título. 
Faculdade de Medicina Veterinária e Zootecnia

Cidade Universitária “Armando de Salles Oliveira”

Comissão Bioética

\section{CERTIFICADO}

Certificamos que o Projeto intitulado "Epidemiologia e controle da brucelose e tuberculose bovinas no Brasil: bases para as intervenções", protocolo $\mathrm{n}^{\circ} 441 / 2004$, utilizando 180 hamsters, sob a responsabilidade do Prof. Dr. José Soares Ferreira Neto, está de acordo com os princípios éticos de experimentação animal da Comissão de Bioética da Faculdade de Medicina Veterinária e Zootecnia da Universidade de São Paulo e foi aprovado pela referida Comissão em sessão de 14/04/04.

(We certify that the Research "Epidemiology and contrl of the bovine brucellosis and tuberculosis in Brazil: basis for the interventions" protocol number 441/2004, utilizing 180 hamsters, under the responsibility of Prof. Dr. José Soares Ferreira Neto, agree with Ethical Principles in Animal Research adopted by Bioethic Commission of the Faculty of Veterinary Medicine and Zootechny of University of São Paulo and was approved in 04/14/2004 meeting.

São Paulo, 16 de abril de 2004

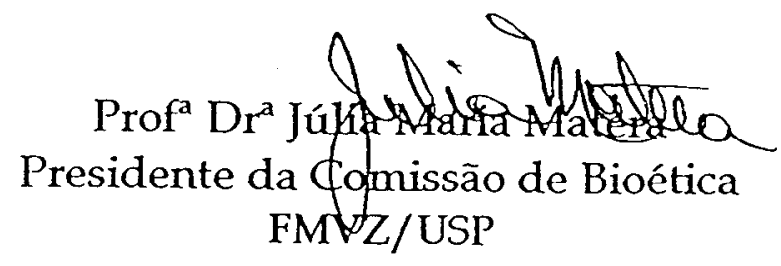

Av. Prof. Dr. Orlando Marques de Paiva. 87 - 05508-000 - Cid. Univ. "Armando de Salles Oliveira" 


\section{FOLHA DE AVALIAÇÃO}

Nome: RIBEIRO, Daniella Carvalho

Título: Comparação de protocolos de extração de DNA para detecção de Mycobacterium bovis através da PCR em homogeneizados de órgãos bovinos

Dissertação apresentada ao Programa de Pós-Graduação em Epidemiologia Experimental e Aplicada às Zoonoses da Faculdade de Medicina Veterinária e Zootecnia da Universidade de São Paulo para obtenção do título de Mestre em Medicina Veterinária

Data:

\section{Banca Examinadora}

Prof.Dr. Instituição:

Assinatura: Julgamento:

Prof.Dr. Instituição:

Assinatura: Julgamento:

Prof.Dr. Instituição:

Assinatura: Julgamento: 
Nada se cria, nada se perde, tudo se transforma. Antoine Laurent Lavoisier $1743-1794$ 
MONTE CASTELO

Composição: Renato Russo

Ainda que eu falasse a língua dos homens.

E falasse a língua dos anjos, sem amor eu nada seria.

É só o amor, é só o amor.

Que conhece o que é verdade.

$\mathrm{O}$ amor é bom, não quer o mal.

Não sente inveja ou se envaidece.

O amor é fogo que arde sem se ver.

É ferida que dói e não se sente.

É um contentamento descontente.

É dor que desatina sem doer.

Ainda que eu falasse a língua dos homens.

E falasse a língua dos anjos, sem amor eu

nada seria.

É um não querer mais que bem querer.

É solitário andar por entre a gente.

É um não contentar-se de contente.

É cuidar que se ganha em se perder.

É um estar-se preso por vontade.

É servir a quem vence, o vencedor;

É um ter com quem nos mata a lealdade.

Tão contrário em si é mesmo o amor.

Estou acordado e todos dormem, todos dormem, todos dormem.

Agora vejo em parte. Mas então veremos face a face.

É só o amor, é só o amor.

Que conhece o que é verdade.

Ainda que eu falasse a língua dos

homens.

E falasse a língua dos anjos, sem amor eu nada seria.

\section{$1^{a}$ Epístola de São Paulo aos Coríntios}

Capítulo 13, versículo 1

Ainda que eu fale a língua dos homens e dos anjos, se eu não tiver amor, serei como bronze que soa ou como o címbalo que retina. Ainda que eu conheça todos os mistérios, se não tiver amor nada serei...

O amor é paciente, é benigno, o amor não arde em ciúmes, não se ufana, não se ensoberbece...O amor jamais acaba. Não se alegra com a injustiça, mas se regozija com a verdade. Quando, porém, vier o que é perfeito, então o que é em parte será aniquilado. Porque agora veremos como em espelho, obscuramente, então veremos face a face; agora eu conheço em parte, então conhecerei também como sou conhecido.

\section{Soneto}

Luís Vaz de Camões

Amor é fogo que arde sem se ver, é ferida que dói, e não se sente; é um contentamento descontente, é dor que desatina semdoer.

É um não querer mais que bem querer; é um andar solitário entre a gente; é nunca contentar-se de contente; é um cuidar que se ganha em se perder.

É querer estar preso por vontade; é servir a quem vence, o vencedor; é ter com quem nos mata, lealdade.

Mas como causar pode seu favor nos corações humanos amizade, se tão contrário a si é o mesmo Amor? 
DEDICATÓRIA

Consagro esta dissertação a Jesus Cristo, agradecendo-O e a Nossa Senhora das Graças.

Dedico aos meus amados Pais, Artur e Graça, pelo infinito e indescritível amor, bem como por sua inerente forma de nos ensinar pelo exemplo,

A minha amada irmã e afilhada, Isabella,

A D. Aldora, avó paterna, e ao Sr. Claro, bisavô materno, in memorium, à base preventiva de nossa família,

Ao Paulo Henrique Guimarães de Oliveira, um exemplo de amor, fortaleza e cumplicidade e

A todos familiares, educadores e amigos por participarem da composição da minha história. 


\section{AGRADECIMENTOS}

A todos Professores e Funcionários do VPS que com sua cordialidade e solicitude exemplares transmitem esses valores a cada aluno e, conseqüentemente é criado o incomparável ambiente de fraternidade desta grande e marcante equipe que é o Departamento de Medicina Veterinária Preventiva e Saúde Animal da FMVZ/USP.

Ao Professor Doutor José Soares Ferreira Neto pela oportunidade ímpar de participar desta equipe, pela orientação e pelos ensinamentos transmitidos, meu afeto, minha admiração e imensurável gratidão.

Ao Professor Doutor Sílvio Arruda de Vasconcellos pela exemplar dedicação profissional e pelo incentivo ao desenvolvimento pessoal dos alunos para que sigamos com ânimo e força rumo aos objetivos que nos aprouverem.

A Professora Doutora Andréa Micke Moreno pelo incalculável auxílio na execução deste experimento e pela hospitalidade com que me acolheu em seu laboratório.

Aos Professores Doutores Simone de Carvalho Balian e Ricardo Augusto Dias pela afeição que destinam àqueles que os circundam e pela colaboração.

A Professora Doutora Sônia Pinheiro pelo empenho em difundir e aplicar os conhecimentos técnicos em pequenas comunidades, indígenas, rurais ou urbanas. E, pela preocupação especial em que eu falasse mais alto...Muito obrigada!

A Sra. Zenaide M. Moraes Higa, uma profissional exemplar e incansável, sempre disposta a compartilhar seus conhecimentos, e a sua bela família, Sr. Tadau, Rafael e sua Mãezinha. Agradeço também pelo aprendizado da vida que levo comigo.

A Gisele, Sr. Orlando Bispo e Sheila, uma família amável, eficiente e que visa ao bem-estar dos que os rodeiam. Gi, você me ajudou muito também a crescer na fé!

A Amane, Flávia, Mariana, Carol, Vivi, Paty, Simone, Ádina, e demais pósgraduandos e estagiários do Laboratório de Zoonoses Bacterianas pela enriquecedora e estimulante convivência.

Eugenia Márcia de Deus Oliveira por ter me apresentado à M. bovis no L.Z.B. e ao carinhoso auxílio.

César Alejandro Rosales Rodriguez pela convivência, "co-orientação" e pelo aprendizado que propiciou a mim.

A Adriana Cortez e a Lara Borges Keid pela humildade em reconhecer as dificuldades e limitações individuais, em compartilhar seus conhecimentos e pelo empenho em auxiliar de forma a estimular o aprendizado. Adriana, agradeço também por ter sido essencial ao meu desenvolvimento pessoal e por descobrir o que faltava eu fazer para o experimento funcionar.

A equipe da Sanidade Suína, em especial a Cleise, Renata, Tânia e Márcia pela prazerosa convivência e pelo inestimável auxílio. Não tenho como agradecê-las.

Às equipes dos Laboratórios de Biologia Molecular, Virologia, Higiene de Alimentos e Parasitárias pela constante ajuda.

À Diretora Rosa Zani, a Elza Faquim, Fátima, Helena, Solange, Márcia, Alexandre e a toda equipe da biblioteca da FMVZ pela sempre cordial ajuda e paixão pelo o que fazem que nos transmitem.

Aos pós-graduandos/graduados, estagiários e funcionários: Alexandre Sanches, Patrícia, Sandrinha, Sérgio, Carol, Letice, Alexandre Thomaz, Ataliba, Renata, Ivan, Cris Brito, Iara, Alessandra, Leslie, Ana Catarina, Franklin, Mikaela, Manuela, Richard, Jonas, Ricardo, Fernanda, Lúcia, Daniel, Cris, Sabrina, Rita, Maria, Fábio, Laura, Luís César, Clarisse, Sônia, Luciana, Giulia, Luísa, Tina, Neide, Pedrinho e D. Anita, dentre tantos que tive o prazer de conhecer. 
Aos "adeptos" de trabalhar aos finais de semana que muito me ensinaram e ajudaram, em especial nessa reta final: Helena Arantes, Maurício, Adriano, Sílvio e Eliana.

A Carol, Jucélia e Sr. Antônio, personalidades fortes e queridas que muito me ajudaram e ensinaram, minha gratidão e admiração.

A Cristina, Virgínia e Danival pelo incansável auxílio e simpatia.

Ao Santos, Luisão, Erivaldo, Fábio, Edson, Conrado e todos outros que garantem a segurança na FMVZ com alegria e simpatia contagiantes.

Ao GRIOT 15 de novembro, em especial, a Gilberto, Meire, Wanderley e Gil, por sua determinação e empenho em prol da edução igualitária e do desenvolvimento humano e social. Parabéns e muito sucesso!

Àqueles que aqui conheci por atuarem na veterinária da conservação, Alessandra Nava, Mônica, Rodrigo (Mogly), Cássio, Déborah, Patricia, Marcelo foi sempre muito animador conversar com vocês.

A Abílio, Kátia, Vanessa e Luís Carlos por momentos inesquecíveis em nossas viagens a Santos pelo Ilha Bela.

Ao Professor João Palermo Neto, Sr. Bispo e a todos que fizeram daquele curso de oratória uma experiência enriquecedora e marcante, em especial, Bel, Gerby, Márcia, Milena, Emily, Paulo, Rosilda, Ana Maria e Fernanda.

A todos da São Patrício, em especial, Sr. Antônio e Carine; a Simone e a equipe do CEFAC e a Aline Davoli pelo essencial auxílio e paciência.

A Tia Socorro e a Karina pelo apoio e indiscutível amor!

Aos meus padrinhos, Ilza e Félix, e filhas, Ana e Helô, pelo carinho e apoio. Ilza, você tinha razão...eu ainda precisaria da matemática!

A Tia Laurinda e Tio John, in memorium, a Cifinha, ao John e a toda família Downey e DeJesus pelo carinho e oportunidade ímpar que me é útil diariamente.

Aos amigos da UFLA: Gláu, Gui, Karen, Dani (BH), Ana, Fábríco, Nêssa, Paschoal, Vinícius, Levy, Coimbra, Gleidiane, Emiliana, Miuky e tantos outros que permanecem em meu coração. A Bel, Leandro, Emerson, Laerte, Sérgio, Henrique, Luciano, Geraldo e Josie, referenciais de "Lavras" que tive o prazer de encontrar na FMVZ.

Aos amigos Paulo Andrade, Augusto, Rosana, Aldeniza, Francis e Pedro pelo apoio e amizade mesmo à distância.

Dentre tantas pessoas especiais que tive o prazer de conhecer melhor durante algumas disciplinas, gostaria de agradecer principalmente, Idelmar, Mieko, Eb, Haroldo, Fabíola, Solange, Wanessa, Ariel, Ana Márcia, Lílian, Hélio, Marcos Sena, Antônio, Gisélia, Cristóvão, Vanessa Dufrayer, Michelle e Juliano.

A Thaís Lourenço e Maria Luíza pela amizade, companhia e auxílio imensuráveis!

A Cristiana Mármore, Ana Luísa e Carlos Eduardo pela amizade

A Juliana Suieko Shimabukuro, a quem admiro e devo o constante apoio anterior até ao meu ingresso no VPS. Também aos seus Pais e amigos, em especial, a Sol, que sempre foram muito queridos e acolhedores.

Especialmente aos professores e amigos Idael Christiano de Almeida Santa Rosa e Francisco Duque de Mesquita Neto, UFLA/MG, por me mostrarem que eu poderia ser veterinária.

A todos professores e demais profissionais cujo trabalho é pautado na medicina veterinária preventiva pela aplicação da epidemiologia e a esse ramo de estudo que fomenta meu anseio em combater a persistente tuberculose e/ou outras instigantes doenças.

A FMVZ, Universidade de São Paulo e CAPES.

Finalmente a toda minha família e àqueles que direta ou indiretamente tenham contribuído com esta etapa e que eu não tenha citado, muitíssimo obrigada! 


\section{RESUMO}

RIBEIRO, D. C. Comparação de protocolos de extração de DNA para detecção de Mycobacterium bovis através da PCR em homogeneizados de órgãos bovinos. [DNA extraction protocols comparison for detecting Mycobacterium bovis by PCR in bovine organs homogenates]. 2006. 55 f. Dissertação (Mestrado em MedicinaVeterinária) - Faculdade de Medicina Veterinária e Zootecnia, Universidade de São Paulo, São Paulo, 2006.

A tuberculose bovina, cujo agente etiológico é o Mycobacterium bovis, é uma zoonose de caráter crônico que representa uma das principais enfermidades em rebanhos bovinos. Devido às perdas consideráveis de bacilos viáveis nos processos de descontaminação, e também pelo consumo de várias semanas entre o isolamento primário e a identificação final da espécie, métodos moleculares funcionam como metodologia diagnóstica auxiliar à bacteriologia clássica. Estes métodos têm ampla aplicação no diagnóstico e tipificação da tuberculose bovina, no entanto, a baixa sensibilidade quando aplicados diretamente sobre homogeneizados de tecidos tem limitado sua difusão como método diagnóstico de rotina. A solução do problema, ao que tudo indica, passa por métodos de extração mais eficientes e menos vulneráveis aos fatores inibidores da amplificação. Assim, foram selecionadas 60 lesões granulomatosas de 60 bovinos condenados em abatedouro, 30 positivas ao isolamento de Mycobacterium bovis (padrão ouro positivo) e 30 negativas (padrão ouro negativo). Dessas lesões foram obtidos homogeneizados que foram submetidos a diferentes protocolos de extração de DNA, que por sua vez foram todos submetidos ao mesmo protocolo de amplificação. Os resultados mostraram que o protocolo de Boom et al. (1990) modificado apresentou sensibilidade superior ao isolamento de $M$. bovis pelo método clássico.

Palavras-chave: Mycobacterium bovis. Bovino. DNA (extração). Reação em cadeia por polimerase. Linfonodos de animais. 


\begin{abstract}
RIBEIRO, D. C. DNA extraction protocols comparison for detecting Mycobacterium bovis by PCR in bovine organs homogenates. [Comparação de protocolos de extração de DNA para detecção de Mycobacterium bovis através da PCR em homogeneizados de órgãos bovinos]. 2006. 55 f. Dissertação (Mestrado em MedicinaVeterinária) - Faculdade de Medicina Veterinária e Zootecnia, Universidade de São Paulo, São Paulo, 2006.
\end{abstract}

The bovine tuberculosis, whose etiological agent is the Mycobacterium bovis, is a major zoonosis of cattle, of chronical course. Due to the expressive loss of viable bacilli during the decontamination processes and the long period between the primary isolation and the final identification of the specie, molecular methods are being used as auxiliary diagnostic methods to the classical bacteriology. These methods have a broad scope of application in the diagnosis and typification of bovine tuberculosis. However, the low sensibility when applied directly to tissue homogenates has limited its application as routine diagnostic method. The answer to this problem, as it seems, is the development of extraction methods that are more efficient and less vulnerable to inhibition factors of amplification. Therefore, 60 granulomatous lesions of 60 condemned bovines at abattoir were selected, 30 Mycobacterium bovis isolation positives (positive gold standard), and 30 negatives (negative gold standard). The homogenates were obtained from these lesions and were subjected to different DNA extraction protocols, all of which were submitted to the same amplification protocol. The results showed that Boom et al. (1990) modified protocol showed superior sensibility than the M. bovis isolation through the classical method.

Key words: Mycobacterium bovis. Bovine. DNA (extraction). Polymerase Chain Reaction. Lymphonodes of animals. 


\section{LISTA DE QUADROS}

Quadro 1 - Descrição dos órgãos que compuseram as amostras selecionadas...... 


\section{LISTA DE TABELAS}

Tabela 1 - Resultados da PCR para detecção de micobactérias do complexo $M$. tuberculosis no grupo padrão ouro positivo de homogeneizados de órgãos bovinos, segundo os protocolos de extração de DNA. São Paulo, 2006

Tabela 2 - Resultados da PCR para detecção de micobactérias do complexo $M$. tuberculosis no grupo padrão ouro negativo de homogeneizados de órgãos bovinos segundo os protocolos de extraçào de DNA. São Paulo, 2006.

Tabela 3 - Resultados da PCR para detecção de micobactérias do complexo $M$. tuberculosis realizado a partir de DNA extraído pelo protocolo de Boom et al. (1990) modificado, segundo os grupos padrão ouro de amostras de homogeneizados de órgãos bovinos. São Paulo, 2006.

Tabela 4 - Resultados da PCR para detecção de micobactérias do complexo $M$. tuberculosis realizado a paratir de DNA extraído pelo protocolo de Santos et al. (1995) modificado, segundo os grupos padrão ouro de amostras de homogeneizados de órgãos bovinos. São Paulo, 2006.

Tabela 5 - Resultados da PCR para deteç̧ão de micobactérias do complexo $M$. tuberculosis realizado a paratir de DNA extraído pelo protocolo de Zumárraga et al. (2001) modificado, segundo os grupos padrão ouro de amostras de homogeneizados de órgãos bovinos. São Paulo, 2006.

Tabela 6 - Valores de sensibilidade e especificidade da PCR para detecção do complexo M. tuberculosis, segundo os protocolos de extração de DNA aplicados em homogeneizados de órgãos bovinos. São Paulo, 2006. 


\section{LISTA DE FIGURAS}

Figura 1 - Gel de agarose mostrando os resultados da PCR realizada com DNA extraído pelo protocolo de Boom et al. (1990) modificado para o volume incial de 2,5 $\mu \mathrm{L}$ em amostras do grupo padrão ouro positivo de homogeneizados de órgãos bovinos. São Paulo, 2006.

Figura 2 - Gel de agarose mostrando os resultados da PCR realizada com DNA extraído pelo protocolo de Zumárraga et al. (2001) modificado para o volume incial de $2,5 \mu \mathrm{L}$ em amostras do grupo padrão ouro positivo de homogeneizados de órgãos bovinos. São Paulo, 2006

Figura 3 - Gel de agarose mostrando os resultados da PCR realizada com DNA extraído pelo protocolo de Santos et al. (1995) modificado para o volume incial de $2,5 \mu \mathrm{L}$ em amostras do grupo padrão ouro positivo de homogeneizados de órgãos bovinos. São Paulo, 2006 


\section{LISTA DE ABREVIATURAS E SIGLAS}

$\begin{array}{ll}\text { AN5 } & \text { estirpe de referência de Mycobacterium bovis } \\ \text { dATP } & \text { desoxi-adenosina trifosfato } \\ \text { dCTP } & \text { desoxi-citosina trifosfato } \\ \text { dGTP } & \text { desoxi-guanidina trifosfato } \\ \text { DNA } & \text { ácido desoxirribonucléico } \\ \text { dTTP } & \text { desoxi-timidina trifosfato } \\ \text { FMVZ/USP } & \text { Faculdade de Medicina Veterinária e Zootecnia da USP } \\ \text { g } & \text { Grama } \\ \text { HPC } & \text { cloreto de hexadecilpiridínio } \\ \text { INS1 } & \text { 5'-CGTGAGGGCATCGAGGTGGC-3' } \\ \text { INS2 } & \text { 5'-GCGTAGGCGTCGGTGACAAA-3' } \\ \text { IS6110 } & \text { seqüência de inserção 6110 } \\ \text { L.Z.B. } & \text { Laboratório de Zoonoses Bacterianas/VPS/FMVZ/USP } \\ \mu \mathrm{g} & \text { Micrograma } \\ \mu \mathrm{L} & \text { Microlitro } \\ \mathrm{M} & \text { molar (mol por litro) } \\ \text { mg } & \text { Miligrama } \\ \text { mL } & \text { Mililitro } \\ \text { p/v } & \text { Peso/volume } \\ \text { pb } & \text { pares de bases } \\ \text { PCR } & \text { reação em cadeia da polimerase } \\ \text { pg } & \text { Picograma } \\ \text { pmol } & \text { Picomol } \\ \text { Rpm } & \text { rotações por minuto } \\ \text { Taq } & \text { Thermus aquaticus } \\ \text { TE } & \text { solução tampão tris-EDTA } \\ \text { TRIS } & \text { Tris (hidroximetil) amino metano } \\ \text { Tris HCl } & \text { Tris (hidroximetil) amino metano com ácido clorídrico } \\ \text { V } & \text { Volts } \\ \text { VPS } & \text { Departamento de Medicina Veterinária Preventiva e Saúde Animal } \\ \text { v/v } & \text { volume/volume } \\ & \end{array}$




\section{SUMÁRIO}

1 INTRODUÇÃ

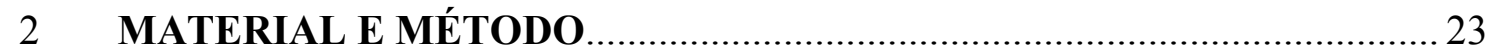

2.1 SELEÇÃO DE AMOSTRAS E COMPOSIÇÃO DOS GRUPOS........................ 23

2.2 PREPARO DO HOMOGENEIZADO DAS LESÕES........................................2 25

2.3 PROTOCOLOS DE EXTRAÇÃO DE ÁCIDOS NUCLÉICOS........................... 25

2.3.1 Protocolo descrito por Boom et al. (1990), modificado............................... 26

2.3.2 Protocolo descrito por Santos et al. (1995), modificado .................................27

2.3.3 Protocolo descrito por Zumárraga et al. (2001), modificado........................ 27

2.4 REAÇÃO EM CADEIA DA POLIMERASE (PCR) .......................................... 29

2.4.1 Concentração dos reagentes para a amplificação de DNA pela PCR............29

2.4. 2 Volume de DNA utilizado para amplificação.............................................. 29

2.4.3 Programa para a amplificação de DNA pela PCR ….................................... 30

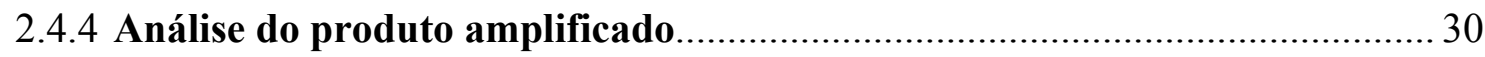

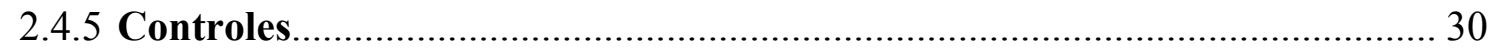

$3 \quad$ RESULTADOS

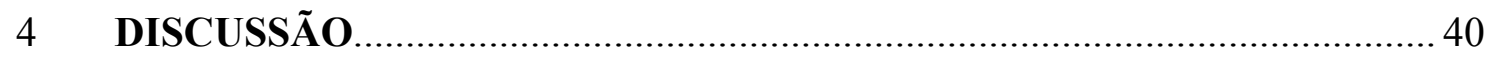

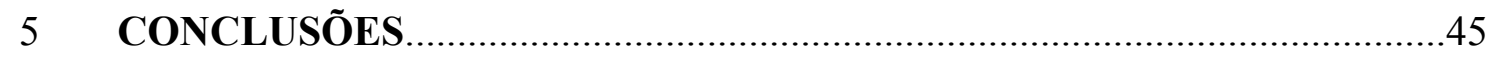

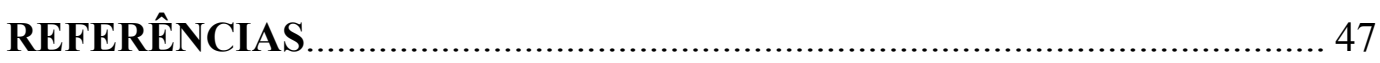

ANEXO 


\section{INTRODUÇÃO}




\section{INTRODUÇÃO}

A tuberculose bovina, cujo agente etiológico é o Mycobacterium bovis, é uma zoonose de caráter crônico e de importância para a pecuária mundial, responsável por perdas econômicas estimadas na casa dos bilhões de dólares (STEELE, 1995), representando uma das principais enfermidades em rebanhos bovinos na América Latina (ZUMÁRRAGA et al., 1999).

A Mycobacterium bovis pertence ao complexo Mycobacterium tuberculosis (MTC), representado pelas micobactérias responsáveis pela tuberculose em humanos e animais domésticos e silvestres, por compartilharem similaridades genômicas, estando incluídas: Mycobacterium tuberculosis, M. africanum, M. microti e M. canetti (ACHA; SZYFRES, 2001; IMAEDA, 1985; SOOLINGEN et al., 1997, 1998; ZANINI et al., 1998) e as recém identificadas, M. caprae e M. pinnipedii (ARANAZ et al., 2003; COUSINS et al., 2003).

A tuberculose bovina foi controlada ou erradicada em grande parte dos países desenvolvidos até a década de 1960 (GRANGE; YATES, 1994). Cosivi et al. (1998) acredita que a tuberculose bovina encontra-se amplamente disseminada na maioria dos países em desenvolvimento, embora a real situação não seja conhecida, pois faltam estudos. Na América Latina, entre 1987 a 1989, dados de condenação por tuberculose em abatedouros bovinos mostraram uma situação bastante heterogênea, com variações entre 0,008 - Uruguai - e 4,1 Argentina - (KANTOR; RITTACO, 1994). No Brasil, os dados de notificações oficiais de tuberculose bovina indicam uma prevalência média nacional de 1,3\% de animais infectados, no período de 1989 a 1998 (BRASIL, 2003). Estudo bem conduzido, realizado em 1999, em sete regiões do Estado de Minas Gerais, envolvendo aproximadamente 1.600 propriedades e 23.000 animais, estimou a prevalência de animais infectados em $0,8 \%$ No mesmo estudo foram detectadas $5 \%$ de propriedades com animais reagentes, sendo importante destacar que este valor subiu a $15 \%$ no universo de propriedades produtoras de leite com algum grau de mecanização da ordenha e de tecnificação da produção (BELCHIOR, 2000).

Embora a tuberculose bovina ainda esteja presente na maioria dos países, o advento da pasteurização e o hábito da fervura do leite reduziram a prevalência de $M$. bovis em humanos (ACHA; SZYFRES, 2001; GRANGE; YATES, 1994). A não ser nos países industrializados, desconhece-se a magnitude real do problema zoonótico causado pela M. bovis (COSIVI et al., 1998), principalmente em decorrência do diagnóstico bacteriológico da tuberculose em humanos geralmente estar limitada à baciloscopia e ao cultivo em meio Lowenstein-Jensen que contém glicerol (ROMERO et al., 1999) no qual o M. bovis apresenta crescimento disgônico, porque utiliza, preferencialmente, o piruvato como uma fonte de carbono 
(YOUMANS, 1976). Estima-se que haja, na América Latina, 7000 novos casos por ano de tuberculose em humanos devido a $M$. bovis, uma taxa de aproximadamente 2 casos por 100.000 habitantes (PAHO, 1991).

O diagnóstico in vivo da tuberculose bovina é feito principalmente pela prova tuberculínica e pela avaliação dos sinais clínicos. A confirmação post mortem baseia-se na bacteriologia (ROXO, 1996) a partir de lesões granulomatosas.

O diagnóstico indireto pelo uso do PPD (Derivado Protéico Purificado) em bovinos apresenta algumas limitações: (1) reações inespecíficas pelo contato prévio com outras micobactérias ambientais resultando em falsos positivos, (2) não reatividade levando a falsos negativos decorrentes de infecção recente, mau estado geral de saúde, imunossupressão pós-parto, anergia etc. (MONOGHAN et al., 1994) e (3) reações cruzadas também com outros patógenos não relacionados como Corynebacterium e Nocardia spp. (ROMERO et al., 1999; YOUMNAS, 1976).

O diagnóstico definitivo da tuberculose bovina é feito através de métodos diretos (LIÉBANA et al., 1995; ROMERO et al., 1999); que consistem no isolamento em meio de LowensteinJensen e Stonebrink-Leslie (CENTRO PANAMERICANO DE ZOONOSIS, 1973) com posterior identificação do agente pelos métodos bacteriológicos clássicos (COUSINS; WILTON; FRANCIS, 1991; GUTIERREZ; OTT; PICON, 1993; HERMANS et al., 1990; JENKINS; DUDDRIDGE, 1985; PAO et al., 1990; THIERRY et al., 1990). Trata-se, portanto, de um processo demorado e trabalhoso, pois o cultivo pode levar dois a três meses e a identificação bioquímica dos isolados, duas a três semanas adicionais (ROMERO et al., 1999). Além do M. bovis apresentar um crescimento fastidioso, os métodos de descontaminação da amostra podem causar perdas na quantidade de bacilos viáveis ao cultivo (LIÉBANA et al., 1996).

Outro método direto, a baciloscopia, representada pela visualização microscópica de bacilos álcool-ácido resistentes (BAAR) em lâminas (decalque de lesão ou suspensão de colônias fixadas pelo calor) corado pela técnica de Ziehl-Neelsen, é um exame apenas presuntivo pois não identifica o agente; além disso, só permite a visualização de BAAR em amostras clínicas muito ricas $\left(\geq 10^{4}\right.$ bacilos $\left./ \mathrm{mL}\right)$, conferindo baixa sensibilidade ao procedimento (BASCUÑANA; BÉLAK, 1996; BENNEDSEN et al., 1996; GUTIERREZ; OTT; PICON, 1993; MARTINS, 2000).

Devido às perdas consideráveis de bacilos viáveis nos processos de descontaminação, e também pelo consumo de várias semanas entre o isolamento primário e a identificação final da espécie, que pode variar de 6 a 8 semanas (BASCUÑANA; BÉLAK, 1996; CORNER, 
1994; COUSINS et al., 1991; HERMANS et al., 1990; PAO et al., 1990; THIERRY et al., 1990; WARDS; COLLINS; LISLE, 1995;), métodos biomoleculares funcionam como metodologia diagnóstica auxiliar à bacteriologia clássica.

Desta forma, um método auxiliar mais rápido, sensível, específico e que não necessite de bactérias viáveis e/ou em grandes quantidades como a PCR - Polymerase Chain Reaction, (COUSINS et al., 1991; HERMANS et al., 1990; OGUSKU et al., 2003; PAO et al., 1990; SAKAMOTO et al., 2001; THIERRY et al., 1990; WARDS; COLLINS; LISLE, 1995; ZANINI et al., 2001) - poderia suprir algumas limitações das técnicas clássicas de isolamento do agente, permitindo a confirmação da presença da micobactéria do complexo $M$. tuberculosis em até 24 horas a partir de amostras suspeitas.

Considerando o uso da PCR, deve-se avaliar os seguintes pontos críticos ao seu sucesso: a escolha correta dos primers (marcador genético polimórfico) a serem empregados e a qualidade da técnica de extração do DNA (BASCUÑANA; BÉLAK, 1996; COLLINS et al., 1994; ZUMÁRRAGA et al., 2001).

Desta forma, a extração e purificação do DNA cromossomal das micobactérias, torna-se um fator limitante ao uso da PCR em amostras clínicas devido à complexidade da parede celular rica em lípides (ACHA; SZYFRES, 2001; JABER et al., 1995; ZHANG; ISHAQUE, 1997). Conseqüentemente, a lise da parede celular para a liberação do DNA íntegro, representa um passo crucial a este processo (WARDS; COLLINS; LISLE, 1995; ZHANG; ISHAQUE, 1997). Outro ponto importante é a natureza intracelular deste patógeno, que dificulta a purificação de organismos de amostras clínicas, especialmente tecidos (WARDS; COLLINS; LISLE, 1995).

Outro agravante é o fato das técnicas propostas para a extração de DNA de M. tuberculosis em amostras clínicas de humanos (escarro) não serem adequadas para a extração de pequena quantidade de DNA de $M$. bovis a partir de homogeneizados de lesões granulomatosas (WARDS ${ }^{1}, 1991$ apud COLLINS et al., 1994, p. 89). Até que este problema seja superado, testes diagnósticos para $M$. bovis baseados em PCR não terão a mesma sensibilidade dos métodos de cultivo bacteriológicos vigentes (COLLINS et al., 1994).

Entretanto, uma das maneiras de aumentar a sensibilidade da PCR para detecção de M. bovis em homogeneizados de tecidos é a utilização de métodos de extração de DNA mais adequados.

Assim, o objetivo do presente estudo foi estudar a sensibilidade e a especificidade diagnósticas de três protocolos de extração de DNA a partir de homogeneizados de tecidos,

${ }^{1}$ WARDS, B. J. personal communication, 1991. 
para a posterior realização da PCR visando a detecção de bactérias do complexo Mycobacterium tuberculosis. 
MATERIAIS E MÉTODOS 


\section{MATERIAIS E MÉTODOS}

Todas as amostras utilizadas no presente estudo são oriundas do projeto "Abatedouros como instrumento de rastreabilidade de focos de tuberculose bovina no estado de SP. Mapeamento e epidemiologia molecular", financiado pela FAPESP (1999/12732-7) e CDA (Coordenadoria de Defesa Agropecuária do Estado de São Paulo). Nesse projeto, 588 amostras de lesões granulomatosas, provenientes de animais condenados por tuberculose em abatedouros entre janeiro de 2002 a janeiro de 2004, foram submetidas à tentativa de isolamento, resultando em 248 isolados caracterizados com M. bovis pelo método spoligotyping (ROSALES RODRIGUEZ, 2005).

\subsection{SELEÇÃO DAS AMOSTRAS E COMPOSIÇÃO DOS GRUPOS}

Para o presente estudo foram selecionadas 60 amostras, sendo 30 positivas ao isolamento clássico (CENTRO PANAMERICANO DE ZOONOSIS, 1973) e confirmadas como Mycobacterium bovis pela técnica de spoligotyping (ROSALES RODRIGUEZ, 2005), as quais compuseram o grupo padrão ouro positivo. Outras 30 lesões, negativas ao isolamento clássico, foram novamente submetidas ao cultivo em meios de Lowenstein-Jensen e Stonebrink-Leslie (CENTRO PANAMERICANO DE ZOONOSIS, 1973) depois de previamente descontaminadas pelo método HPC (cloreto de hexadecilpiridínio), conforme descrição de Ambrósio (2005). Essas amostras foram incubadas a $37^{\circ} \mathrm{C}$ por 90 dias. As amostras que resultaram negativas a essa segunda tentativa de isolamento compuseram o grupo padrão ouro negativo. $\mathrm{O}$ quadro 1 mostra os órgãos que compuseram cada uma das amostras selecionadas. 
(continua)

\begin{tabular}{|c|c|}
\hline AMOSTRA & ÓRGÃO \\
\hline \multicolumn{2}{|c|}{ grupo padão ouro positivo } \\
\hline $47 / 03$ & linfonodo \\
\hline $51 / 03$ & linfonodo \\
\hline $54 / 03$ & linfonodo, pulmão \\
\hline $67 / 03$ & linfonodo \\
\hline $74 / 03$ & linfonodo, pulmão \\
\hline $75 / 03$ & linfonodo, pulmão \\
\hline $80 / 03$ & linfonodo \\
\hline $81 / 03$ & linfonodo \\
\hline $85 / 03$ & linfonodo \\
\hline $92 / 03$ & linfonodo, pulmão \\
\hline $112 / 03$ & linfonodo, pulmão \\
\hline $126 / 03$ & linfonodo \\
\hline $127 / 03$ & linfonodo, fígado \\
\hline $129 / 03$ & linfonodo \\
\hline $142 / 03$ & linfonodo \\
\hline $167 / 03$ & linfonodo \\
\hline 209/03 & linfonodo, pulmão \\
\hline $215 / 03$ & linfonodo \\
\hline $224 / 03$ & linfonodo, pulmão \\
\hline $256 / 03$ & linfonodo \\
\hline $278 / 03$ & linfonodo, pulmão, fígado \\
\hline $288 / 03$ & linfonodo \\
\hline $295 / 03$ & linfonodo \\
\hline $319 / 03$ & linfonodo \\
\hline $325 / 03$ & linfonodo \\
\hline $338 / 03$ & linfonodo, pulmão \\
\hline $339 / 03$ & linfonodo \\
\hline $356 / 03$ & linfonodo \\
\hline $407 / 03$ & linfonodo, pulmão, fígado \\
\hline $414 / 03$ & linfonodo, pulmão \\
\hline \multicolumn{2}{|c|}{ grupo padrão ouro negativo } \\
\hline $05 / 02$ & linfonodo, tubérculo na cavidade torácica \\
\hline $17 / 03$ & linfonodo, hilo hepático \\
\hline $97 / 03$ & linfonodo, pulmão \\
\hline $103 / 03$ & indeterminado \\
\hline $120 / 03$ & carcaça \\
\hline $157 / 03$ & linfonodo \\
\hline $166 / 03$ & pulmão \\
\hline $183 / 03$ & linfonodo \\
\hline $185 / 03$ & linfonodo \\
\hline $187 / 03$ & linfonodo \\
\hline $200 / 03$ & linfonodo \\
\hline
\end{tabular}

Quadro 1 - Descrição dos órgãos que compuseram as amostras selecionadas 
(conclusão)

\begin{tabular}{|ll|}
\hline AMOSTRA & ÓRGÃO \\
\hline grupo padão ouro negativo & \\
$211 / 03$ & linfonodo, pulmão, diafragma, fígado \\
$228 / 03$ & linfonodo, diafragma \\
$242 / 03$ & linfonodo \\
$251 / 03$ & linfonodo \\
$276 / 03$ & linfonodo \\
$284 / 03$ & linfonodo \\
$318 / 03$ & linfonodo \\
$359 / 03$ & linfonodo, pulmão \\
$368 / 03$ & indeterminado \\
$423 / 03$ & linfonodo \\
$431 / 03$ & linfonodo \\
$454 / 03$ & linfonodo, pulmão \\
$455 / 03$ & linfonodo \\
$483 / 03$ & linfonodo \\
$490 / 03$ & linfonodo \\
$525 / 03$ & linfonodo, fígado \\
$535 / 03$ & linfonodo, fígado, coração \\
$18 / 04$ & linfonodo \\
\hline
\end{tabular}

Quadro 1 - Descrição dos órgãos que compuseram as amostras selecionadas

\subsection{PREPARO DO HOMOGENEIZADO DAS LESÕES}

Os homogeneizados dessas 60 lesões foram diluídas 1:10 e 1:100 e essas 180 amostras foram submetidas aos três diferentes métodos de extração de DNA.

\subsection{PROTOCOLOS DE EXTRAÇÃO DE ÁCIDOS NUCLÉICOS}

Dentre os três protocolos de extração de DNA testados, um foi previamente aplicado a lesões granulomatosas bovinas (ZUMÁRRAGA et al., 2001), outro em bactérias gram-positivas (BOOM et al., 1990) e o terceiro é utilizado para a extração de DNA de Mycobacterium leprae, agente etiológicico da hanseníase humana, a partir de pêlos sobre lesões cutâneas, pele e secreção nasal (SANTOS et al., 1995). 
A cada três amostras, foi incluído um controle negativo, (TE), e ao final da bateria de extração, um controle positivo oriundo de colônias de M. bovis estirpe AN5.

Os três protocolos foram inicialmente validados com colônias puras de M. bovis estirpe AN5.

\subsubsection{Procololo descrito por Boom et al. (1990), modificado}

Adicionar $100 \mu \mathrm{l}$ de lisosima $(100 \mu \mathrm{g} / \mathrm{ml})$.

Acrescentar $20 \mu \mathrm{l}$ de proteinase $\mathrm{K}$.

Vortex por 1minuto.

Banho Maria a $37^{\circ} \mathrm{C}$ por 1 hora.

$1 \mathrm{ml}$ do tampão de lise (Anexo A).

Vortex por $1 \mathrm{~min}$.

Acrescentar $40 \mu \mathrm{l}$ de sílica.

Vortex por 1 minuto.

Aguardar 20 minutos `a temperatura ambiente.

Centrifugar por $1,5 \mathrm{~min}$ a $12800 \mathrm{rpm}$.

Descartar o sobrenadante.

Adicionar $500 \mu$ de tampão de lavagem (Anexo A).

Vortex por 15 segundos.

Centrifugar $1,5 \mathrm{~min}$ a $12800 \mathrm{rpm}$.

Descartar todo sobrenadante.

Adicionar $500 \mu \mathrm{l}$ de tampão de lavagem, agitar por $15 \mathrm{seg}$, centrifugar por $1,5 \mathrm{~min}$ e descartar o sobrenadante.

Lavagem com: $500 \mu \mathrm{l}$ de etanol a 70\%, vortex por 15 segundos, centrifugar por 1,5 min e descartar o sobrenadante. Repetir este passo.

Adicionar $500 \mu \mathrm{l}$ de acetona P.A., vortex por 15 segundos, centrifugar por $2 \mathrm{~min}$ e descartar o sobrenadante.

Secar na estufa a $37^{\circ}$ por 30 minutos.

Adicionar $150 \mu \mathrm{l}$ de tampão de eluição (Anexo A).

Vortex por 1 minuto.

Banho Maria a $55^{\circ} \mathrm{C}$ por 10 minutos.

Vortex por 1 minuto. 
Centrifugar por 5 min a $12800 \mathrm{rpm}$.

Transferir $100 \mu \mathrm{l}$ do sobrenadante para um eppendorf novo.

Centrifugar por $5 \mathrm{~min}$ a $12800 \mathrm{rpm}$.

Se houver restos de sílica no fundo do tubo, transfira o sobrenadante para outro tubo.

Manter a amostra congelada a $-20^{\circ} \mathrm{C}$ até a amplificação.

\subsubsection{Protocolo descrito por Santos et al. (1995), modificado}

Centrifugar por 15 minutos a $13200 \mathrm{rpm}$.

Desprezar o sobrenadante.

Adicionar $50 \mu \mathrm{L}$ de $\mathrm{NaOH}$ a $0,5 \mathrm{M}$.

Manter sob leve agitação por 10 minutos.

Adicionar $50 \mu \mathrm{L}$ de $\mathrm{Na}_{2} \mathrm{H}_{2} \mathrm{PO}_{4}$ a $1 \mathrm{M}$.

Manter sob leve agitação por 10 minutos.

Centrifugar a $13200 \mathrm{rpm}$ por 10 minutos à temperatura ambiente.

Desprezar o sobrenadante.

Adicionar $60 \mu \mathrm{L}$ de TE $1 \%$ Triton $100 \mathrm{X}$ e $50 \mu \mathrm{L}$ de proteinase $\mathrm{K}(10 \mathrm{mg} / \mathrm{ml})$.

Incubar a amostra a $37^{\circ} \mathrm{C}$, overnight.

Submeter as amostras a três ciclos de fervura (por $10 \mathrm{~min}$ ) e congelamento em nitrogênio líquido (por 2 minutos).

Manter a amostra congelada a $-20^{\circ} \mathrm{C}$ até a amplificação.

\subsubsection{Protocolo descrito por Zumárraga et al. (2001), modificado}

$1^{\circ}$ DIA

Adicionar $100 \mu \mathrm{L}$ de SDS $10 \%$ e $10 \mu \mathrm{L}$ de proteinase K $(10 \mathrm{mg} / \mathrm{ml})$.

Incubar a $65^{\circ} \mathrm{C}$ por 30 minutos.

Ferver por 10 minutos.

Aguardar por 5 min a temperatura ambiente.

Spin por 15 segundos antes do próximo passo. 
Adicionar $50 \mu \mathrm{L}$ de lisosima e incubar a $37^{\circ} \mathrm{C}$ overnight.

$2^{\circ}$ DIA

Spin por 15 segundos.

Fazer uma lavagem com $750 \mu \mathrm{L}$ de fenol: clorofórmio: álcool isoamílico (25:24:1).

Vortex por 15 segundos.

Centrifugar por $7 \mathrm{~min}$, a $12800 \mathrm{rpm}$.

Transferir o sobrenadante para um microtubo novo (aproximadamente $250 \mu \mathrm{L}$ ).

Lavagem com $500 \mu \mathrm{L}$ de clorofórmio : álcool isoamílico (24:1), vortex.

Centrifugar por $7 \mathrm{~min}$, a $12800 \mathrm{rpm}$.

Transferir o sobrenadante para um microtubo novo (aproximadamente $150 \mu \mathrm{L}$ ).

Adicionar $100 \mu \mathrm{L}$ de $\mathrm{NaCl}$ a $5 \mathrm{M}$, spin por 15 segundos.

Adicionar 2 volumes de etanol 100\%.

Congelar a $-20^{\circ} \mathrm{C}$ overnight.

$3^{\circ}$ DIA

Centrifugar por $15 \mathrm{~min}$ a $13200 \mathrm{rpm}$.

Descartar o sobrenadante deixando apenas cerca de $20 \mu \mathrm{L}$.

Fazer uma lavagem com 1,0 $\mathrm{ml}$ de etanol $70 \%$, vortex.

Centrifugar por $5 \mathrm{~min}$ a $13200 \mathrm{rpm}$.

Fazer outra lavagem com etanol 70\% e centrifugar por 5 minutos.

Descartar todo sobrenadante.

Centrifugar por $15 \mathrm{~min}$ a $13200 \mathrm{rpm}$.

Deixar o pellet secar a $37^{\circ} \mathrm{C}$ por no mínimo 30 minutos.

Ressuspender em $50 \mu \mathrm{L}$ ou $30 \mu \mathrm{L}$ de TE, segundo o tamanho do pellet.

Congelar as amostras a $-20^{\circ} \mathrm{C}$ até a amplificação. 


\subsection{REAÇÃO EM CADEIA DA POLIMERASE (PCR)}

A amplificação foi realizada conforme descrito por Hermans et al. (1990). Foram utilizados os primers INS1 (5'-CGTGAGGGCATCGAGGTGGC-3') e INS2 (5'-GCGTAGGCGTCGGTGACAAA-3') direcionados à seqüência de inserção IS6110 (THIERRY et al., 1990), gerando um fragmento de DNA com 245 pares de base, específico do complexo Mycobacterium tuberculosis.

\subsubsection{Concentração dos reagentes para a amplificação de DNA pela PCR}

Os reagentes utilizados para a amplificação estavam na seguinte concentração: $1,25 \mathrm{mM}$ de cada oligonucleotídeo (dCTP, dATP, dGTP, dTTP), tampão de reação 5X Green Go Taq ${ }^{\mathrm{TM}}$ (Promega, Madison, WI, USA) 10 pMol de cada primer, 1,25 Unidades de Platinum Taq DNA Polimerase (Invitrogen, Carisbad, Califórnia, USA), $5 \mu \mathrm{L}$ da solução contendo o DNA extraído e $26,75 \mu \mathrm{L}$ (e 2,5 $\mu \mathrm{L}$ de DNA e $29,25 \mu \mathrm{L}$ ) de água ultra pura obtida em aparelho MilliQ-Millipore Inc. (Billerica, MA, USA).

O volume final da solução para a amplificação consistiu de $50 \mu \mathrm{L}$, sendo $5 \mu \mathrm{L}$ de DNA e 45 $\mu \mathrm{L}$ de mix e $2,5 \mu \mathrm{L}$ de DNA e $47,5 \mu \mathrm{L}$ de mix.

\subsubsection{Volume de DNA utilizado para a amplificação}

Foram utilizados $5 \mu \mathrm{L}$ de DNA com as 180 amostras resultantes de cada um dos três diferentes métodos de extração e reações adicionais com 2,5 $\mu \mathrm{L}$ de DNA foram realizadas com os homogeneizados iniciais. 


\subsubsection{Programa para a amplificação de DNA pela PCR}

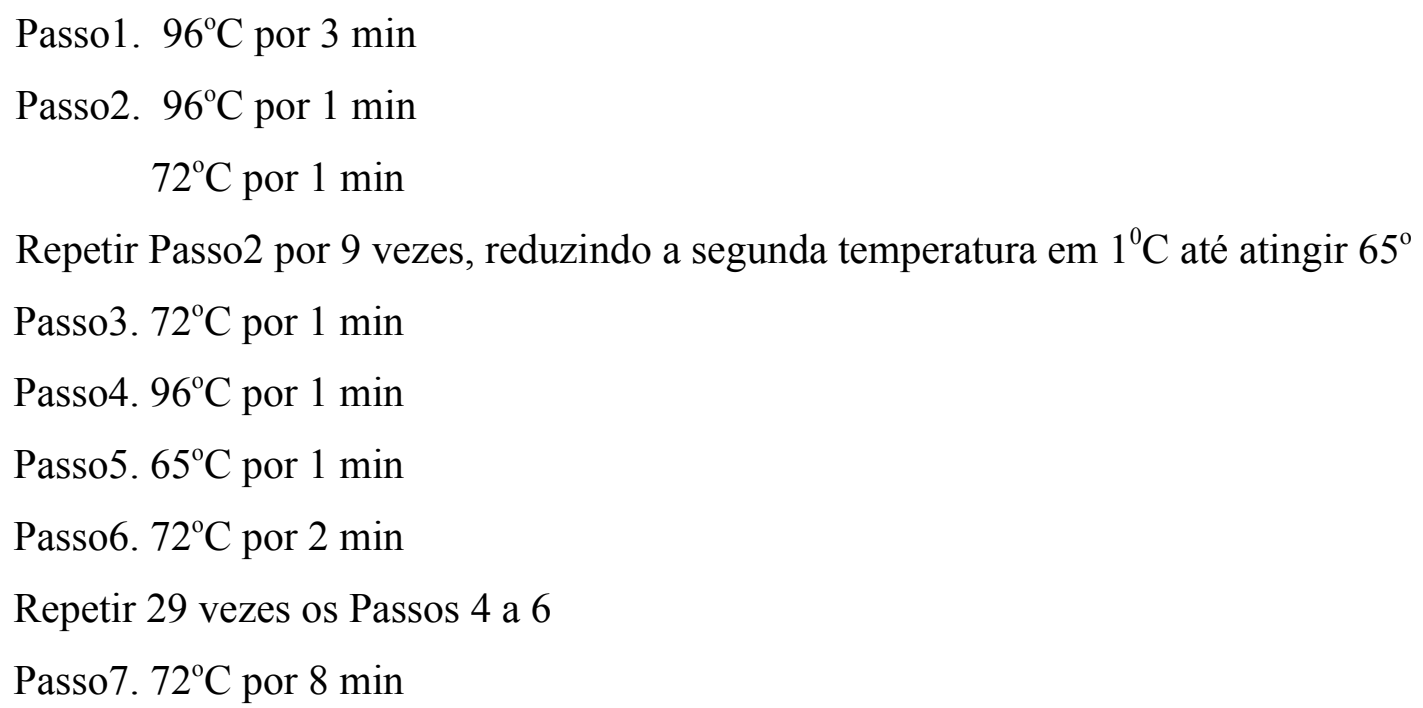

\subsubsection{Análise do produto amplificado}

$10 \mu \mathrm{L}$ do produto amplificado de cada reação foram analisados pela técnica de eletroforese em gel de agarose a 1,5\% (p/v), em cuba horizontal com tampão de corrida TBE 0,5X (0,045M Tris-borato e $1 \mathrm{mM}$ EDTA, $\mathrm{pH} 8,0)$, sob a voltagem constante de 6-7 V/ cm.

As bandas de 245 pares de bases foram visualizadas em transiluminador ultravioleta, 20 minutos após a imersão do gel numa solução de brometo de etídio a $0,5 \mu \mathrm{g} / \mathrm{mL}$ (SAMBROOK; FRITCH; MANIATIS, 1989). O padrão de peso molecular utilizado para comparar às bandas consistia de fragmentos múltiplos de 100 pares de base.

\subsubsection{Controles}

Foram tomadas as precauções para se evitar a contaminação de utensílios e equipamentos de laboratório com material genético (DIEFFENBACH et al., 1995), além da inclusão de controles positivos e negativos em todas reações. Prevenindo-se assim, o risco de falsos positivos, bem como de falhas na PCR. 
RESULTADOS 


\section{RESULTADOS}

Não foi obtido nenhum isolado de BAAR no grupo padrão ouro negativo.

Os resultados da PCR para detecção de micobactérias do complexo M. tuberculosis, segundo os três protocolos de extração de DNA ensaiados, constam das tabelas 1 e 2 . 
Tabela 1 - Resultados da PCR para detecção de micobactérias do complexo M. tuberculosis no grupo padrão ouro positivo de homogeneizados de órgãos bovinos, segundo os protocolos de extração de DNA - São Paulo - 2006

\begin{tabular}{|c|c|c|c|c|c|c|c|c|c|c|c|c|}
\hline $\begin{array}{l}\text { Protocolo de } \\
\text { extração }\end{array}$ & \multicolumn{4}{|c|}{$\begin{array}{c}\text { Boom et al. (1990) } \\
\text { modificado }\end{array}$} & \multicolumn{4}{|c|}{$\begin{array}{c}\text { Zumárraga et al. (2001) } \\
\text { modificado }\end{array}$} & \multicolumn{4}{|c|}{$\begin{array}{c}\text { Santos et al. (1995) } \\
\text { modificado }\end{array}$} \\
\hline Volume inicial & \multirow{2}{*}{$\frac{2,5 \mu \mathrm{L}}{10^{0}}$} & \multicolumn{3}{|c|}{$5 \mu \mathrm{L}$} & \multirow{2}{*}{$\begin{array}{c}2,5 \mu \mathrm{L} \\
10^{0} \\
\end{array}$} & \multicolumn{3}{|c|}{$5 \mu \mathrm{L}$} & \multirow{2}{*}{$\begin{array}{c}2,5 \mu \\
L \\
10^{0} \\
\end{array}$} & \multicolumn{3}{|c|}{$5 \mu \mathrm{L}$} \\
\hline Diluição & & $10^{\circ}$ & $10^{-1}$ & $10^{-2}$ & & $10^{0}$ & $10^{-1}$ & $10^{-2}$ & & $10^{0}$ & $10^{-1}$ & $10^{-2}$ \\
\hline Número da amostra & & & & & & & & & & & & \\
\hline $47 / 03$ & ${ }^{\mathrm{I}} \mathrm{P}$ & II- & - & - & - & - & - & - & - & - & - & - \\
\hline $51 / 03$ & $\mathrm{P}$ & - & - & - & - & - & - & - & $\mathrm{P}$ & - & - & - \\
\hline $54 / 03$ & $\mathrm{P}$ & - & - & - & - & - & - & - & $\mathrm{P}$ & - & - & - \\
\hline $67 / 03$ & $\mathrm{P}$ & - & - & - & - & - & - & - & $\mathrm{P}$ & - & - & - \\
\hline $74 / 03$ & $\mathrm{P}$ & - & - & - & - & - & - & - & - & - & - & - \\
\hline $75 / 03$ & $\mathrm{P}$ & - & - & - & - & - & - & - & - & - & - & - \\
\hline $80 / 03$ & $\mathrm{P}$ & $\mathrm{P}$ & $\mathrm{P}$ & - & - & - & - & - & - & - & - & - \\
\hline $81 / 03$ & $\mathrm{P}$ & - & - & - & - & - & - & - & - & - & - & - \\
\hline $85 / 03$ & $\mathrm{P}$ & - & - & - & - & - & - & - & - & - & - & - \\
\hline $92 / 03$ & $\mathrm{P}$ & - & $\mathrm{P}$ & - & - & - & - & - & $\mathrm{P}$ & - & - & - \\
\hline $112 / 03$ & $\mathrm{P}$ & $\mathrm{P}$ & - & - & $\mathrm{P}$ & - & - & - & - & $\mathrm{P}$ & - & - \\
\hline $126 / 03$ & $\mathrm{P}$ & $\mathrm{P}$ & - & - & - & - & - & - & - & - & - & - \\
\hline $127 / 03$ & $\mathrm{P}$ & - & $\mathrm{P}$ & - & - & - & - & - & - & - & - & - \\
\hline $129 / 03$ & $P$ & $\mathrm{P}$ & - & - & - & - & - & - & - & - & - & - \\
\hline $142 / 03$ & $\mathrm{P}$ & $\mathrm{P}$ & - & - & $\mathrm{P}$ & - & - & - & - & - & - & - \\
\hline $167 / 03$ & $\mathrm{P}$ & $\mathrm{P}$ & $\mathrm{P}$ & - & $\mathrm{P}$ & $\mathrm{P}$ & $\mathrm{P}$ & $\mathrm{P}$ & $\mathrm{P}$ & $\mathrm{P}$ & - & - \\
\hline $209 / 03$ & $\mathrm{P}$ & $\mathrm{P}$ & - & - & - & - & - & - & - & - & - & - \\
\hline $215 / 03$ & $\mathrm{P}$ & $\mathrm{P}$ & $\mathrm{P}$ & - & $\mathrm{P}$ & $\mathrm{P}$ & $\mathrm{P}$ & $\mathrm{P}$ & $\mathrm{P}$ & $\mathrm{P}$ & - & - \\
\hline $224 / 03$ & $\mathrm{P}$ & $\mathrm{P}$ & $\mathrm{P}$ & - & - & - & $\mathrm{P}$ & $\mathrm{P}$ & - & - & - & - \\
\hline $256 / 03$ & - & $\mathrm{P}$ & - & - & $\mathrm{P}$ & - & - & - & - & - & - & - \\
\hline $278 / 03$ & $\mathrm{P}$ & $\mathrm{P}$ & $\mathrm{P}$ & - & - & - & $\mathrm{P}$ & - & - & - & - & - \\
\hline $288 / 03$ & $\mathrm{P}$ & $\mathrm{P}$ & $\mathrm{P}$ & $\mathrm{P}$ & $\mathrm{P}$ & $\mathrm{P}$ & - & - & - & $\mathrm{P}$ & - & - \\
\hline $295 / 03$ & $\mathrm{P}$ & $\mathrm{P}$ & - & - & - & - & - & - & $\mathrm{P}$ & $\mathrm{P}$ & - & - \\
\hline $319 / 03$ & $\mathrm{P}$ & $\mathrm{P}$ & $\mathrm{P}$ & - & $\mathrm{P}$ & $\mathrm{P}$ & $\mathrm{P}$ & - & $\mathrm{P}$ & - & - & - \\
\hline $325 / 03$ & $\mathrm{P}$ & $\mathrm{P}$ & $\mathrm{P}$ & - & $\mathrm{P}$ & - & $\mathrm{P}$ & - & $\mathrm{P}$ & - & - & - \\
\hline $338 / 03$ & $\mathrm{P}$ & $\mathrm{P}$ & - & - & $\mathrm{P}$ & $\mathrm{P}$ & - & - & $\mathrm{P}$ & $\mathrm{P}$ & - & - \\
\hline $339 / 03$ & $\mathrm{P}$ & $\mathrm{P}$ & - & $\mathrm{P}$ & $\mathrm{P}$ & $\mathrm{P}$ & - & - & $\mathrm{P}$ & - & - & - \\
\hline $356 / 03$ & $\mathrm{P}$ & $\mathrm{P}$ & $\mathrm{P}$ & $\mathrm{P}$ & - & - & - & - & - & - & - & - \\
\hline $407 / 03$ & $\mathrm{P}$ & $\mathrm{P}$ & - & - & $\mathrm{P}$ & $\mathrm{P}$ & - & - & $\mathrm{P}$ & - & - & - \\
\hline $414 / 03$ & $\mathrm{P}$ & $\mathrm{P}$ & $\mathrm{P}$ & - & $\mathrm{P}$ & $\mathrm{P}$ & $\mathrm{P}$ & $\mathrm{P}$ & $\mathrm{P}$ & - & - & - \\
\hline positivos/examinados & $29 / 30$ & $20 / 30$ & $12 / 30$ & $3 / \mathbf{3 0}$ & $12 / 30$ & $8 / 30$ & $7 / 30$ & $4 / 30$ & $12 / 30$ & $6 / 30$ & $\mathbf{0} / \mathbf{3 0}$ & $\mathbf{0} / 30$ \\
\hline positivos/examinados & & $30 / 30$ & & & & $13 / 30$ & & & & $17 / 30$ & & \\
\hline
\end{tabular}

(I) positivos. (II) negativos. 
Tabela 2 - Resultados da PCR para detecção de micobactérias do complexo M. tuberculosis no grupo padrão ouro negativo de homogeneizados de órgãos bovinos segundo os protocolos de extração de DNA. São Paulo, 2006

\begin{tabular}{|c|c|c|c|c|c|c|c|c|c|c|c|c|}
\hline \multirow{3}{*}{$\begin{array}{r}\begin{array}{r}\text { Protocolo de } \\
\text { extração }\end{array} \\
\text { Volume inicial } \\
\text { Diluição } \\
\end{array}$} & \multicolumn{4}{|c|}{$\begin{array}{c}\begin{array}{c}\text { Boom et al. (1990) } \\
\text { modificado }\end{array} \\
\end{array}$} & \multicolumn{4}{|c|}{$\begin{array}{c}\begin{array}{c}\text { Zumárraga et al. (2001) } \\
\text { modificado }\end{array} \\
\end{array}$} & \multicolumn{4}{|c|}{$\begin{array}{c}\begin{array}{c}\text { Santos et al. (1995) } \\
\text { modificado }\end{array} \\
\end{array}$} \\
\hline & \multirow{2}{*}{\begin{tabular}{|c|}
$2,5 \mu \mathrm{L}$ \\
$10^{\circ}$ \\
\end{tabular}} & \multicolumn{3}{|c|}{$5 \mu \mathrm{L}$} & \multirow{2}{*}{\begin{tabular}{|c|}
$2,5 \mu \mathrm{L}$ \\
$10^{\circ}$ \\
\end{tabular}} & \multicolumn{3}{|c|}{$5 \mu \mathrm{L}$} & \multirow{2}{*}{\begin{tabular}{|c|}
$2,5 \mu \mathrm{L}$ \\
$10^{\circ}$ \\
\end{tabular}} & \multicolumn{3}{|c|}{$5 \mu \mathrm{L}$} \\
\hline & & $10^{0}$ & $10^{-1}$ & $10^{-2}$ & & $10^{0}$ & $10^{-1}$ & $10^{-2}$ & & $10^{\circ}$ & $10^{-1}$ & $10^{-2}$ \\
\hline Número da amostra & & & & & & & & & & & & \\
\hline $05 / 02$ & II - & ${ }^{\mathrm{I}} \mathrm{P}$ & - & - & $\mathrm{P}$ & $\mathrm{P}$ & - & - & $\mathrm{P}$ & $\mathrm{P}$ & - & - \\
\hline $17 / 03$ & $P$ & $\mathrm{P}$ & - & - & $\mathrm{P}$ & $\mathrm{P}$ & - & - & $\mathrm{P}$ & $\mathrm{P}$ & - & - \\
\hline $97 / 03$ & - & $\mathrm{P}$ & - & - & - & - & - & - & - & - & - & - \\
\hline $103 / 03$ & $\mathrm{P}$ & $\mathrm{P}$ & - & - & - & - & - & - & - & - & - & - \\
\hline $120 / 03$ & - & $\mathrm{P}$ & - & - & - & - & - & - & - & - & - & - \\
\hline $146 / 03$ & $\mathrm{P}$ & $\mathrm{P}$ & - & - & - & - & - & - & - & - & - & - \\
\hline $157 / 03$ & $P$ & $\mathrm{P}$ & - & - & $\mathrm{P}$ & $\mathrm{P}$ & - & - & - & - & - & - \\
\hline $166 / 03$ & $\mathrm{P}$ & $\mathrm{P}$ & - & - & $\mathrm{P}$ & $\mathrm{P}$ & - & - & - & $\mathrm{P}$ & - & - \\
\hline $183 / 03$ & $\mathrm{P}$ & $\mathrm{P}$ & - & - & $\mathrm{P}$ & $\mathrm{P}$ & - & - & $\mathrm{P}$ & $\mathrm{P}$ & - & - \\
\hline $185 / 03$ & $\mathrm{P}$ & $\mathrm{P}$ & - & - & $\mathrm{P}$ & $\mathrm{P}$ & - & - & - & $\mathrm{P}$ & - & - \\
\hline $187 / 03$ & $\mathrm{P}$ & $\mathrm{P}$ & - & - & $\mathrm{P}$ & - & - & - & $\mathrm{P}$ & $\mathrm{P}$ & - & - \\
\hline $200 / 03$ & - & - & $\mathrm{P}$ & - & - & - & - & - & $\mathrm{P}$ & - & - & - \\
\hline $211 / 03$ & $\mathrm{P}$ & $\mathrm{P}$ & - & - & - & - & - & - & - & - & - & - \\
\hline $222 / 03$ & $\mathrm{P}$ & $\mathrm{P}$ & - & - & - & - & - & - & - & - & - & - \\
\hline $228 / 03$ & - & - & - & - & - & - & - & - & - & - & - & - \\
\hline $242 / 03$ & - & - & - & - & - & - & - & - & - & - & - & - \\
\hline $276 / 03$ & - & - & - & - & - & - & - & - & - & - & - & - \\
\hline $284 / 03$ & - & - & - & - & - & - & - & - & - & - & - & - \\
\hline $318 / 03$ & - & - & - & - & - & - & - & - & - & - & - & - \\
\hline $359 / 03$ & - & - & - & - & - & - & - & - & - & - & - & - \\
\hline $368 / 03$ & - & - & - & - & - & - & - & - & - & - & - & - \\
\hline $423 / 03$ & $\mathrm{P}$ & $\mathrm{P}$ & - & - & $\mathrm{P}$ & $\mathrm{P}$ & - & - & - & - & - & - \\
\hline $431 / 03$ & $\mathrm{P}$ & $\mathrm{P}$ & - & - & $\mathrm{P}$ & $\mathrm{P}$ & - & - & - & - & - & - \\
\hline $454 / 03$ & $\mathrm{P}$ & $\mathrm{P}$ & - & - & $\mathrm{P}$ & $\mathrm{P}$ & - & - & $\mathrm{P}$ & - & - & - \\
\hline $455 / 03$ & - & - & - & - & - & - & - & - & - & - & - & - \\
\hline $483 / 03$ & - & - & - & - & $\mathrm{P}$ & $\mathrm{P}$ & - & - & - & - & - & - \\
\hline $490 / 03$ & - & $\mathrm{P}$ & - & - & - & - & - & - & $\mathrm{P}$ & - & - & - \\
\hline $525 / 03$ & $\mathrm{P}$ & $\mathrm{P}$ & - & - & - & - & - & - & - & $\mathrm{P}$ & - & - \\
\hline $535 / 03$ & - & - & - & - & - & - & - & - & - & - & - & - \\
\hline $18 / 04$ & $\mathrm{P}$ & $\mathrm{P}$ & - & - & - & $\mathrm{P}$ & - & - & $\mathrm{P}$ & $\mathrm{P}$ & - & - \\
\hline positivos/examinados & $16 / 30$ & $19 / 30$ & $1 / 30$ & $\mathbf{0} / \mathbf{3 0}$ & $11 / 30$ & $11 / 30$ & $\mathbf{0} / \mathbf{3 0}$ & $\mathbf{0} / \mathbf{3 0}$ & $8 / 30$ & $8 / 30$ & $\mathbf{0} / \mathbf{3 0}$ & $0 / 30$ \\
\hline positivos/examinados & & $20 / 30$ & & & & $12 / 30$ & & & & $10 / 30$ & & \\
\hline
\end{tabular}

(I) positivos. (II) negativos. 
As figuras 1 a 3 consistem de géis da PCR com 2,5 $\mu \mathrm{L}$ dos dez primeiros homogeneizados do grupo padrão ouro positivo submetidas aos três protocolos de extração, sendo o fragmento com 245 pares de base representativo de micobactérias do complexo M. tuberculosis. Controles negativo e positivos estão incluídos bem como marcadores de peso moleculares de 100 e 50 pares de base.

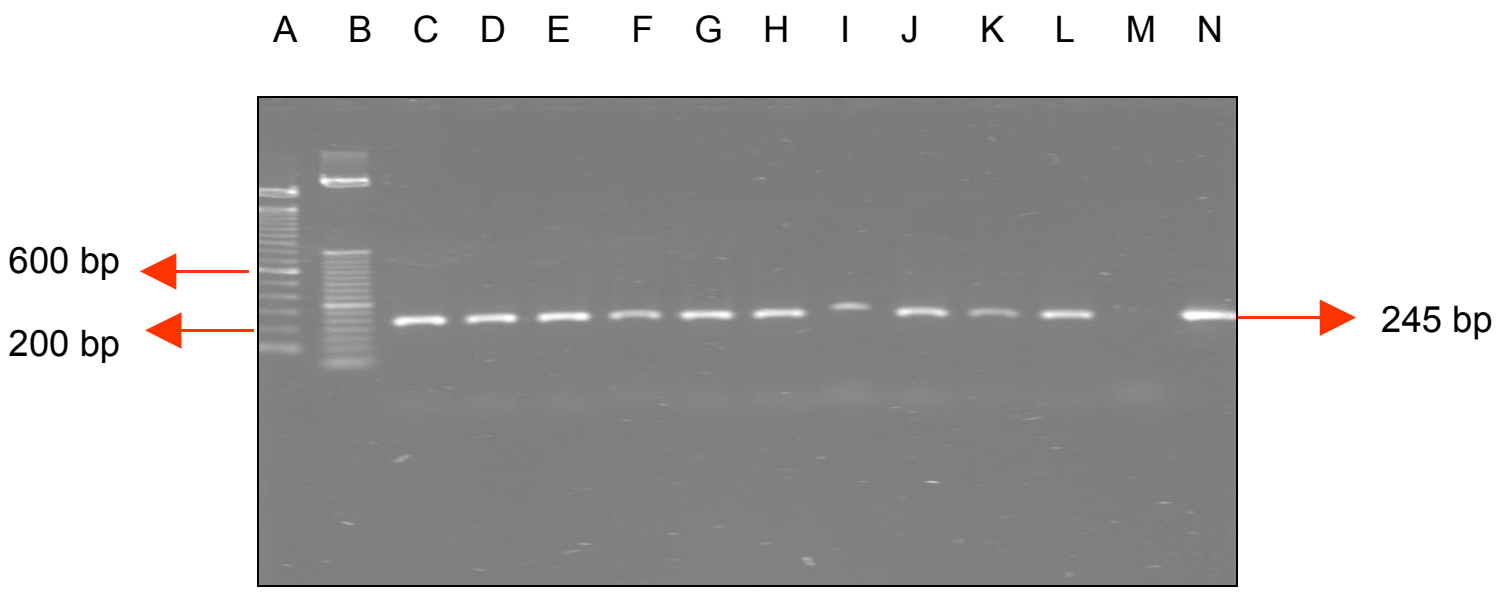
A:. Ladder $100 \mathrm{bp}$; B.. Ladder $50 \mathrm{bp}$; $\mathrm{C}$ a $\mathrm{L}: 1^{\circ}$ ao $10^{\circ}$ homogeneizados padrão ouro positivos, respectivamente; M: Controle negativo e N: Controle positivo (Mycobacterium bovis, estirpe AN5).

Figura 1 - Gel de agarose mostrando os resultados da PCR realizada com DNA extraído pelo protocolo de Boom et al. (1990) modificado para o volume inicial de $2,5 \mu \mathrm{L}$ em amostras do grupo padrão ouro positivo de homogeneizados de órgãos bovinos São Paulo - 2006 


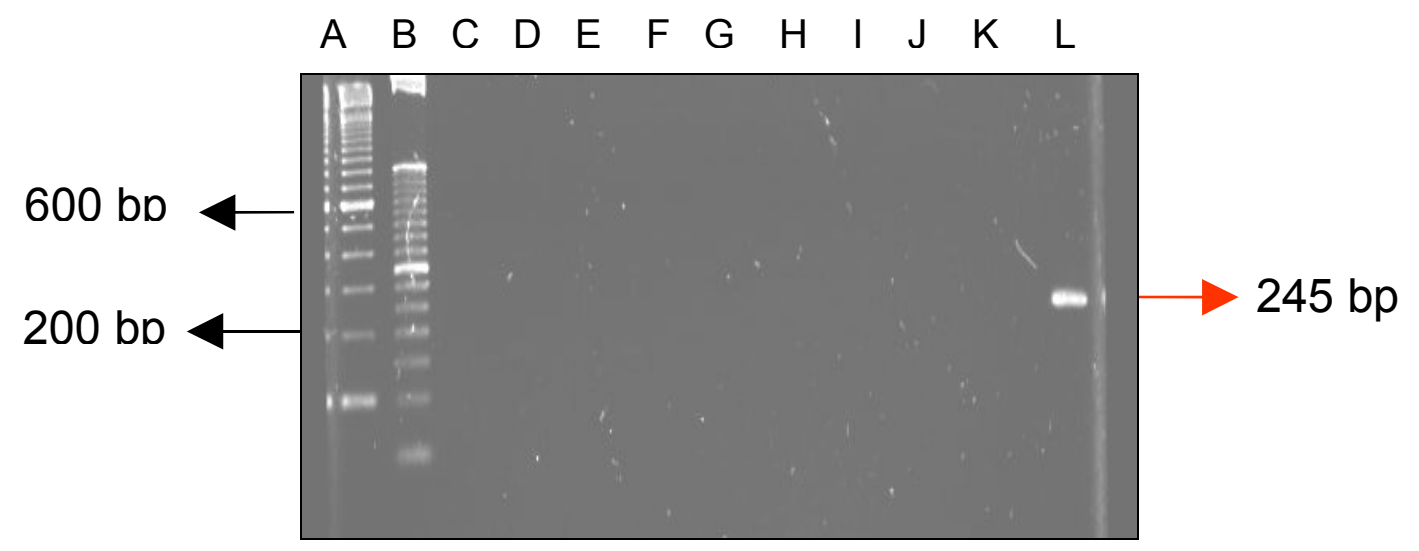

A:. Ladder 100 bp; B:. Ladder 50 bp; $\mathrm{C}$ a L: $1^{\circ}$ ao $10^{\circ}$ homogeneizados padrão ouro positivos, respectivamente; M: Controle negativo e N: Controle positivo (Mycobacterium bovis, estirpe AN5).

Figura 2 - Gel de agarose mostrando os resultados da PCR realizada com DNA extraído pelo protocolo de Zumárrga et al. (2001) modificado para o volume inicial de 2,5 $\mu \mathrm{L}$ em amostras do grupo padrão ouro positivo de homogeneizados de órgãos bovinos. São Paulo, 2006

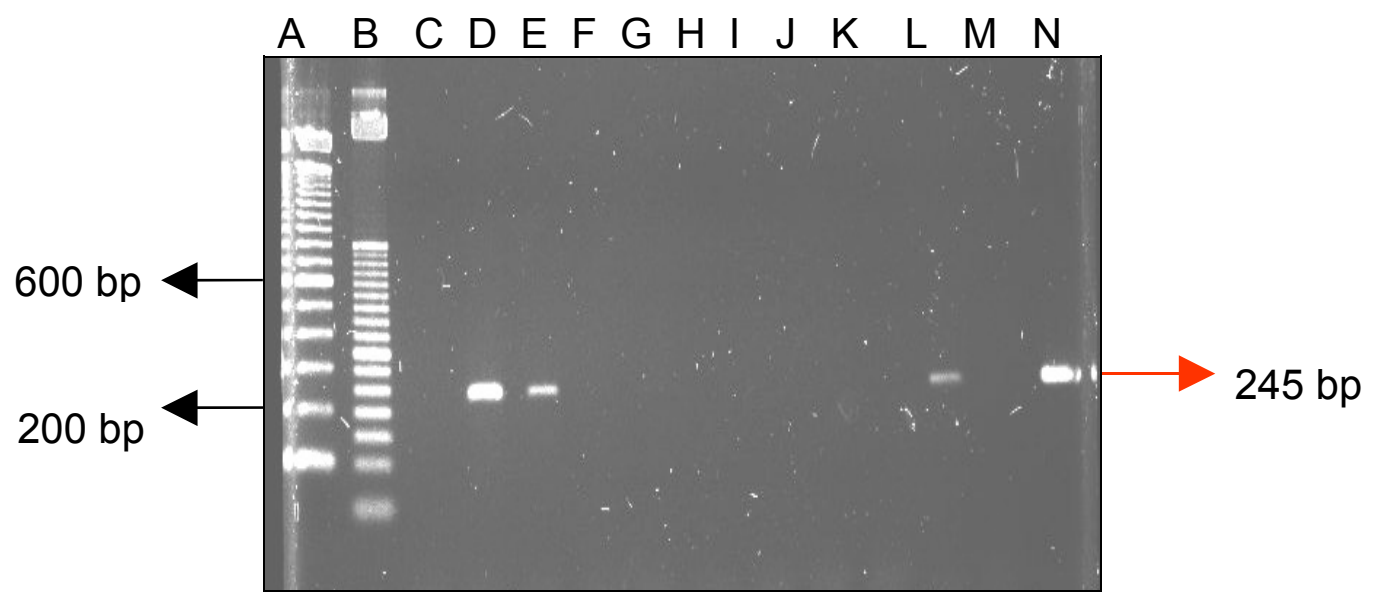

A:. Ladder 100 bp; B:. Ladder 50 bp; $\mathrm{C}$ a L: $1^{\circ}$ ao $10^{\circ}$ homogeneizados padrão ouro positivos, respectivamente; M: Controle negativo e N: Controle positivo (Mycobacterium bovis, estirpe AN5).

Figura 3 - Gel de agarose mostrando os resultados da PCR realizada com DNA extraído pelo protocolo de Santos et al. (1995) modificado para o volume inicial de $2,5 \mu \mathrm{L}$ em amostras do grupo padrão ouro positivo de homogeneizados de órgãos bovinos São Paulo - 2006 
A partir das tabelas 1 e 2 foram elaboradas as tabelas 3 a 5, nas quais foram calculados os valores de sensibilidade e especificidade diagnósticas. Como existem quatro reações de PCR para cada protocolo de extração de DNA (diferentes diluições e volumes utilizados na fase de amplificação), as tabelas abaixo foram construídas considerando-se como positivas as reações de PCR que resultaram em amplificação de fragmento de 245 pb para pelo menos uma das reações ensaiadas por protocolo de extração, ou seja, foi aplicada uma interpretação em paralelo dos resultados da PCR.

Tabela 3 - Resultados da PCR para detecção de micobactérias do complexo Mycobacterium tuberculosis realizado a partir de DNA extraído pelo protocolo de Boom et al. (1990) modificado, segundo os grupos padrão ouro de amostras de homogenei- zado de órgãos bovinos - São Paulo - 2006

\begin{tabular}{l|c|c|c}
\hline \multicolumn{1}{c|}{$\begin{array}{c}\text { Padrão ouro } \\
\text { Resultado do protocolo de extração }\end{array}$} & $\begin{array}{c}\text { Isolamento } \\
\text { positivo }\end{array}$ & $\begin{array}{c}\text { Isolamento } \\
\text { negativo }\end{array}$ & Total \\
\hline PCR positiva & 30 & 20 & 50 \\
PCR negativa & 0 & 10 & 10 \\
Total & 30 & 30 & 60 \\
\hline
\end{tabular}

Sensibilidade $=100 \%$; Especificidade $=33,33 \%$.

Tabela 4 - Resultados da PCR para detecção de micobactérias do complexo Mycobacterium tuberculosis realizado a partir de DNA extraído pelo protocolo de Santos et al. (1995) modificado, segundo os grupos padrão ouro de amostras de homogeneizado de órgãos bovinos - São Paulo - 2006

\begin{tabular}{l|c|c|c}
\hline \multicolumn{1}{c|}{$\begin{array}{c}\text { Padrão ouro } \\
\text { Resultado do protocolo de extração }\end{array}$} & $\begin{array}{c}\text { Isolamento } \\
\text { positivo }\end{array}$ & $\begin{array}{c}\text { Isolamento } \\
\text { negativo }\end{array}$ & Total \\
\hline PCR positiva & 15 & 10 & 25 \\
PCR negativa & 15 & 20 & 35 \\
Total & 30 & 30 & 60 \\
\hline
\end{tabular}

Sensibilidade $=50 \%$; Especificidade $=66,6 \%$. 
Tabela 5 - Resultados da PCR para detecção de micobactérias do complexo $M$. tuberculosis realizado a partir de DNA extraído pelo protocolo de Zumárraga et al. (2001) modificado, segundo os grupos padrão ouro de amostras de homogenei- zado de órgãos bovinos - São Paulo - 2006

\begin{tabular}{l|c|c|c}
\hline \multicolumn{1}{c|}{$\begin{array}{c}\text { Padrão ouro } \\
\text { Resultado do protocolo de extração }\end{array}$} & $\begin{array}{c}\text { Isolamento } \\
\text { positivo }\end{array}$ & $\begin{array}{c}\text { Isolamento } \\
\text { negativo }\end{array}$ & Total \\
\hline PCR positiva & 13 & 12 & 25 \\
PCR negativa & 17 & 18 & 35 \\
Total & 30 & 30 & 60 \\
\hline
\end{tabular}

Sensibilidade $=43,3 \%$; Especificidade $=60 \%$.

Os resultados das sensibilidades e especificidades diagnósticas para as três diluições dos homogeneizados submetidos aos três protocolos de extração de DNA estão resumidos na tabela 6.

Tabela 6 - Valores de sensibilidade e especificidade da PCR para detecção do complexo $M$. tuberculosis, segundo os protocolos de extração de DNA aplicados em homogeneizados de órgãos bovinos - São Paulo - 2006

\begin{tabular}{l|c|c}
\hline \multicolumn{1}{c|}{ Protocolo de extração } & $\begin{array}{c}\text { Sensibilidade } \\
\text { diagnóstica (\%) }\end{array}$ & $\begin{array}{c}\text { Especificidade } \\
\text { diagnóstica (\%) }\end{array}$ \\
\hline Boom et al. (1990) modificado & 100 & 33,33 \\
Zumárraga et al. (2001) modificado & 43,3 & 60,0 \\
Santos et al. (1995) modificado & 50 & 66,6 \\
\hline
\end{tabular}


DISCUSSÃ̃ 


\section{DISCUSSÃO}

A tentativa de isolamento no grupo padrão ouro negativo não revelou nenhum novo isolado de micobactéria e, portanto, os grupos padrão ouro permaneceram os mesmos, com 30 amostras cada.

Para cada protocolo de extração foram realizadas quatro reações de PCR, que diferiram na diluição do homogeneizado e no volume da amostra utilizado para iniciá-lo. Como o objetivo foi comparar os protocolos, optou-se por interpretar os resultados em paralelo, ou seja, foi considerado como resultado negativo apenas os protocolos de extração que não apresentaram amplificação de 245 pb para as quatro variações ensaiadas.

Embora os resultados tenham sido interpretados em paralelo, a observação das tabelas 1 e 2 mostra que, exceto para a amostra 200/03 (Tabela 2), os melhores resultados sempre foram obtidos realizando-se as PCRs a partir do homogeneizado puro $\left(10^{\circ}\right)$, com volumes iniciais de $2,5 \mu \mathrm{L}$ e $5,0 \mu \mathrm{L}$.

A melhor sensibilidade foi obtida pelo protocolo de Boom et al. (1990) modificado (100\%), seguido por Santos et al. (1995) modificado (50\%) e Zumárraga et al. (2001) modificado $(43,3 \%)$. Importante salientar que no protocolo de Boom et al. (1990) aqui utilizado não consta o uso da alfa caseína, preconizada por Boom et al. (1999) para a eliminação de possíveis inibidores de PCR atribuídos ao complexo sílica-isotiocianato de guanidina. A mesma recomendação foi feita por Zanini et al. (2001) para a detecção de MTC em tecido bovino.

Zanini et al. (2001) realizaram cultivo e identificação clássica em 54 amostras de linfonodos colhidos de 54 animais condenados por tuberculose em abatedouros, dos quais foram obtidos 23 isolados de M. bovis. Homogeneizados dessas mesmas amostras foram submetidas à extração de DNA pelo método de Boom et al. (1999), o qual envolve a lise com o isotiocianato de guanidina com a utilização de $\alpha$-caseína e pela purificação dos ácidos nucléicos com a sílica (diatomaceous earth), seguida de amplificação com primers INS1 e INS2 (HERMANS et al., 1990). Considerando o cultivo como padrão ouro, a sensibilidade da PCR foi de $100 \%$, resultado igual ao encontrado no presente estudo.

Zumárraga et al. (2001) realizaram cultivo e identificação clássica em 12 linfonodos colhidos durante a necropsia de 4 bezerros positivos a PPD, dos quais foram obtidos 12 isolados de $M$. bovis. Homogeneizados dessas mesmas amostras foram submetidas à extração de DNA pelo método desenvolvido pelos autores, o qual envolve a lise enzimática com lisosima e 
proteinase K, purificação com fenol, clorofórmio, álcool isoamílico, seguida de amplificação com primers INS1 e INS2 (HERMANS et al., 1990). Considerando o cultivo como padrão ouro, a sensibilidade da PCR também foi de $100 \%$.

Liébana et al. (1995) selecionaram 84 bovinos de uma propriedade foco de tuberculose e 16 de uma livre. Ao abate, foram colhidas lesões granulomatosas e na ausência destas, linfonodos mediastínicos, retrofaríngeos, bronquiais e fragmentos de pulmão. Todas as amostras foram submetidas à tentativa de isolamento e identificação pelos métodos clássicos e PCR com extração pela lise enzimática com proteinase K e purificação com Kit comercial e amplificação com os primers IS41 e IS43, direcionados ao elemento IS6110, que amplificam fragmento de $317 \mathrm{pb}$. Considerando o cultivo como padrão ouro foi obtida uma sensibilidade de $71,4 \%$.

Embora existam inúmeros fatores que comprometem a sensibilidade da PCR em amostras clínicas (AL-SOUD; RADSTRÖM, 2001; BENNEDSEN et al., 1996; ROSSEN et al., 1992; WILSON, 1997), a presença de inibidores da amplificação é o principal (Nolte et al., 1993). Assim, pelos resultados obtidos, pode-se concluir que os protocolos Zumárraga et al. (2001) e Santos et al. (1995) modificados estão sujeitos a um efeito maior desses fatores do que o protocolo de Boom et al. (1990) modificado.

Examinando o protocolo de Zumárraga et al. (2001) modificado, sua baixa sensibilidade poderia estar associada à insuficiente purificação (fenol, clorofórmio e álcool isoamílico), pois uma lavagem foi suprimida. Consequentemente, haveria um aumento da quantidade de inibidores de amplificação, como debris celulares, leucócitos e até reagentes. Isto estaria de acordo com a afirmação de Wilson (1997) que atribui como principal fonte de inibição da PCR, a contaminação endógena pela presença de substâncias decorrentes da purificação insuficiente da amostra.

A baixa sensibilidade do protocolo de Santos et al. (1995) modificado pode estar relacionada à presença de inibidores representados por debris celulares (AL-SOUD; RADSTRÖM, 2001; WILSON, 1997) ou NaOH e TritonX 10\%, reagentes utilizados nesse protocolo (ALDOUS et al., 2005; ROSSEN et al., 1992). Por ter sido um protocolo desenvolvido especificamente para $M$. leprae, deve-se levar em consideração a potencial interferência ocasionada por diferenças na constituição da parede celular de ambos agentes (DRAPER, 1976).

As especificidades observadas foram de 33,3\%, 60,0\% e 66,6\%, respectivamente para os protocolos de Boom et al. (1990) modificado, Zumárraga et al. (2001) modificado e Santos et al. (1995) modificado. Importante salientar que o padrão ouro negativo foi constituído por amostras com lesão granulomatosa macroscópica, das quais não houve isolamento de 
micobactérias. Considerando que as lesões bovinas têm uma pequena quantidade de bacilos (WARDS; COLLINS; LISLE, 1995) e que os procedimentos de descontaminação da amostra (Petroff e HPC), que precedem a semeadura em meios de cultivo, são deletérios às micobactérias (BENNEDSEN et al., 1996; LIÉBANA et al., 1996; YAJKO et al., 1995) é plausível concluir que parte dessas amostras classificadas como negativas pelo cultivo, na verdade o foram por falta de sensibilidade desse método. Assim sendo, pode-se afirmar que as amostras do grupo padrão ouro negativo que resultaram positivas para pelos um método de extração continham MTC. A possibilidade de resultados de PCR falsos positivos foi controlada pela utilização de controles positivos e negativos em todas as reações. Resultados semelhantes foram observados por Zanini et al. (2001) que, trabalhando com linfonodos de bovinos, obtiveram resultados positivos à PCR em nove cultivos negativos e seis contaminados. Liébana et al. (1995), em experimento já descrito anteriormente, verificaram uma especificidade de $96,1 \%$ da PCR frente ao cultivo.

O diagnóstico pela PCR apresenta o potencial de detectar DNA de um único organismo de uma espécie pré-determinada em poucos dias ou menos (WRIGHT; WYNFORD-THOMAS, 1990). A PCR, quando aplicada em amostras clínicas, tem como limite mínimo de detecção uma quantidade entre 1 a 100 bacilos do complexo M. tuberculosis (BENNEDSEN et al., 1996). Os primers INS1 e INS2 amplificam um fragmento de $245 \mathrm{pb}$ da seqüência de inserção IS986 (KOLK et al., 1992), que difere da IS987 (HERMANS et al., 1991) e da IS6110 (THIERRY et al., 1990) por alguns poucos pares de bases, e por isso, devem ser considerados o mesmo elemento, exceto quando o objeto de estudo for uma cópia específica (EMBDEN et al., 1993). O M. tuberculosis possui oito cópias de IS986 e o M. bovis BCG apenas uma (SOOLINGEN et al., 1991) e, portanto, a sensibilidade da PCR para esses dois agentes reflete a diferença do número de repetições dessa seqüência nos seus genomas (KOLK et al., 1992). Além disso, primers direcionados a essa seqüência não diferenciam os dois agentes. Mishra et al. (2005) desenvolveram um nested-PCR capaz de diferenciar M. tuberculosis de M. bovis. Futuros estudos poderiam esclarecer se a associação do protocolo de Boom et al. (1990) modificado a esse nested-PCR poderia aperfeiçoar o diagnóstico direto da tuberculose.

Wards, Collins e Lisle (1995) relataram não haver necessariamente relação entre o número de colônias de $M$. bovis visualizadas ao isolamento primário e a eficiência da amplificação. Isto foi enfatizado por Vaneechoute e Eldere (1997) ao afirmarem que a quantificação do produto da PCR não pode ser necessariamente relacionada ao número de organismos presentes na amostra original. Além disso, Kox et al. (1994) afirmaram que grandes quantidades de DNA são amplificadas com menor eficiência do que pequenas quantidades devido ao efeito platô 
que ocorre primeiro em grandes quantidades de DNA-alvo. Entretanto, o efeito platô pode ter pouca importância em amostras de bovinos, visto que apresentam pequena quantidade de bacilos (WARDS; COLLINS; LISLE, 1995).

Portanto, os dados indicaram que o protocolo de Boom et al. (1990) modificado superou um importante fator limitante à aplicação da PCR na rotina diagnóstica da tuberculose bovina, qual seja, extrair eficientemente os poucos $M$. bovis presentes no interior das lesões granulomatosas de tecidos bovinos e expor seus DNAs de tal forma que permita a sua amplificação pela PCR. 
CONCLUSÕES 


\section{CONCLUSÕES}

Com base nos resultados obtidos pelo presente estudo foi possível concluir que:

A PCR utilizando o protocolo de extração de Boom et al. (1990) modificado apresentou sensibilidade superior ao isolamento de M. bovis pelo método clássico. 
REFERÊNCIAS 


\section{REFERÊNCIAS}

ACHA, P. N.; SZYFRES, B. Zoonosis y enfermedades transmisibles comunes al hombre y a los animales. Washington: Organización Panamericana de la Salud, 2001. 398 p. (Publicación Científica y Técnica, n.580)

ALDOUS, W. K.; POUNDER, J. I.; CLOUD, J. L.; WOODS, G. L. Comparison of six methods of extracting Mycobacterium tuberculosis DNA from processed sputum for testing by quantitative real-time PCR. Journal of Clinical Microbiology, v. 43, n. 5, p. 2471-2473, 2005 .

AL-SOUD, W.; RADSTROM, P. Purification and characterization of PCR-inhibitory components in blood cells. Journal of Clinical Microbiology, v. 39, n. 2, p. 485-493, 2001.

AMBRÓSIO, S. R. Métodos bacteriológicos aplicados à tuberculose bovina: comparação de três métodos de descontaminação e de três protocolos para criopreservação de isolados. 2005. 61 f. Dissertação (Mestrado em Medicina Veterinária) - Faculdade de Medicina Veterinária e Zootecnia, Universidade de São Paulo, São Paulo, 2005.

ARANAZ, A.; COUSINS, D.; MATEOS, A.; DOMÍNGUEZ, L. Elevation of Mycobacterium tuberculosis subsp. caprae Aranaz et al. 1999 to species rank as Mycobacterium caprae comb. nov., sp. nov. International Journal of Systematic and Evolutionary Microbiology, v. 53, n. 6, p. 1785-1789, 2003.

BASCUÑANA, C. R.; BELÁK, K. Detection and identification of mycobacteria in formalinfixed, paraffin-embedded tissues by nested PCR and restriction enzyme analysis. Journal of Clinical Microbiology, v. 34, n. 10, p. 2351-2355, 1996.

BELCHIOR, A. P. C. Prevalência, distribuição regional e fatores de risco da tuberculose bovina em Minas Gerais. 2000. 55 f. Dissertação (Mestrado em Medicina Veterinária) Universidade Federal de Minas Gerais, Belo Horizonte, 2000.

BENNEDSEN, J.; THOMSEN, V. O.; PFYFFER, G. E.; FUNKE, G.; FELDMANN, K.; BENEKE, A.; JENKINS, P. A.; HEGGINBOTHOM, M.; FAHR, A.; HENGSTLER, M.; CLEATOR, G.; KLAPPER, P.; WILKINS, E. G. L. Utility of PCR in diagnosing pulmonary tuberculosis. Journal of Clinical Microbiology, v. 34, n. 6, p. 1407-1411, 1996.

BOOM, R.; SOL, C.; BELD, M.; WEEL, J.; GOUDSMIT, J.; DILLEN, P. W. Improved silica-guanidiniumthiocyanate DNA isolation procedure based on selective binding of bovine alpha-casein to silica particles. Journal of Clinical Microbiology, v. 37, n. 3, p. 615-619, 1999. 
BOOM, R.; SOL, C. J. A.; SALIMANS, M. M. M.; JANSEN, C. L.; WERTHEIM DILLEN, P. M. E.; NOORDAA, J. Rapid and simple method for purification of nucleic acids. Journal of Clinical Microbiology, v. 28, n. 3, p. 495-503, 1990.

BRASIL. Ministério da Agricultura, Pecuária e Abastecimento. Breve diagnóstico da situação atual. Disponível em: $<\underline{\text { http://www.agricultura.gov.br/sda/dda/cps_pncebt } 2 . h t m>}$. Acesso em: 28 out. 2003.

CENTRO PANAMERICANO DE ZOONOSIS. Metodos de laboratório de micobacteriologia veterinaria para el aislamiento e identificacion de micobacterias. Buenos Aires: Centro Panamericano de Zoonosis, 1973. 48 p. (Séries de Monografias Científicas y Tecnicas, 6).

COLLINS, D. M.; RADFORD, A. J.; LISLE, W.; BILMAN-JACOBE, H. Diagnosis and epidemiology of bovine tuberculosis using molecular biological approaches. Veterinary Microbiology, v. 40, p. 83-94, 1994.

CORNER, L. A. Post mortem diagnosis of Mycobacterium bovis in cattle. Veterinary Microbiology, v. 40, n. 1-2, p. 53-63, 1994.

COSIVI, O.; GRANGE, J. M.; DABORN, C. J.; RAVIGLIONE, M. C.; FUJIKURA, T.; COUSINS, D.; ROBINSON, R. A.; HUCHZERMEYER, H. F. A. K.; KANTOR, I.; MESLIN, F. X. Zoonotic tuberculosis dute to Mycobacterium bovis in developing countries. Emerging Infectious Diseases, v. 4, n. 1, p. 59-70, 1998.

COUSINS, D. V.; BASTIDA, R.; CATALDI, A.; QUSE, V.; REDROBE, S.; DOW, S.; DUIGNA, P.; MURRAY, A.; DUPONT, C.; AHMED, N.; COLLINS, D. M.; BUTLER, W. R.; DAWSON, D.; RODRÍGUEZ, D.; LOUREIRO, J.; ROMANO, M. I.; ALITO, A.; ZUMARRAGA, M.; BERNARDELLI, A. Tuberculosis in seals caused by a novel member of the Mycobacterium tuberculosis complex: Mycobacterium pinnipedii sp. nov. International Journal of Systematic and Evolutionary Microbiology, v. 53, n. 5, p. 1305-1314, 2003.

COUSINS, D. V.; WILTON, S. D.; FRANCIS, B. R. Use of DNA amplification for the rapid identification of Mycobacterium bovis. Veterinary Microbiology, v. 27, p. 187-195, 1991.

DIFFENBACH, C. W.; DRAGON, E. A.; DVEKSLER, G. S. Setting up a PCR laboratory. In: DIEFFENBACH, C. W.; DVEKSLER, G. S. (Ed.). PCR primer: a laboratory manual. New York: Cold Spring Harbor Laboratory Press, 1995. p. 7-16.

DRAPER, P. Cell walls of Mycobacterium leprae. International Journal of Leprosy, v. 44, n. 1-2, p. 156-159, 1976. 
EMBDEN, J. D. A.; CAVE, M. D.; CRAWFORD, J. T.; JEREMY, W. D.; EISENACH, K. D.; GICQUEL, B.; HERMANS, P.; MARTIN, C.; MCADAM, R.; SHINNICK, T. M.; SMALL, P. M. Strain identification of Mycobacterium tuberculosis by DNA fingerprinting, recommendations for a standardized methodology. Journal of Clinical Microbiology, v. 31, n. 2, p. 406-409, 1993.

GRANGE, J. M.; YATES, M. D. Zoonotic aspects of Mycobacterium bovis infection. Veterinary Microbiology, v. 40, p. 137-151, 1994.

GUTIERREZ, M. J.; OTT, W. P.; PICON, P. D. Métodos diagnósticos. In: PICON, P. D.; RIZZON, C. F. C.; OTT, W. P. Tuberculose: epidemiologia, diagnóstico e tratamento em clínica e saúde pública. Rio de Janeiro: MESDI, 1993. p. 21-34.

HERMANS, P. W.; SOOLINGEN, D.; BIK, E. M.; HAAS, P. E. W.; DALE, J. W.; EMBDEN, J. D. A. Insertion element IS987 from Mycobacterium bovis BCG is located in a hot-spot integration region for insertion elements in Mycobacterium tuberculosis complex strains. Infection and Immunity, v. 59, n. 8, p. 2695-2705, 1991.

HERMANS, P. W. M.; SOOLINGEN, D.; DALE, J. W.; SCHUITEMA, A. R.; MCADAM, R. A.; CATTY, D.; EMBDEN, J. D. A. Insertion element IS987 from M. tuberculosis: a useful tool for diagnosis and epidemiology of tuberculosis. Journal of Clinical Microbiology, v. 28, n. 9 , p. 2051-2058, 1990.

IMAEDA, T. Deoxyribonucleic acid relatedness among selected strains of Mycobacterium tuberculosis, Mycobacterium bovis, Mycobacterium bovis BCG, Mycobacterium microti and Mycobacterium africanum. International Journal of Systematic Bacteriology, v. 35, n. 2, p. 147-150, 1985.

JABER, M.; RATTAN, A.; VERMA, A.; TYAGI, J.; KUMAR, R. A simple method of DNA extraction from Mycobacterium tuberculosis. Tubercle and Lung Disease, v. 76, p. 578-581, 1995.

KANTOR, I. N.; RITACCO, V. Bovine tuberculosis in Latin America and the Caribbean: current status, control and eradication programs. Veterinary Microbiology, v. 40, p. 5-14, 1994.

JENKINS, P. A.; DUDDRIDGE, L. R. Mycobacteria. In: COLLINS, C. H.; GRANGE, J. M. Isolation and identification of micro-organisms of medical and veterinary importance. London: Academic Press, 1985. p. 275-295. (The Society for Applied Bacteriology Technical Series, 21). 
KOLK, A. H. J.; SCHUITEMA, A. R. J.; KUIJPER, S.; VAN LEEUWEN, J.; HERMANS, P. W. M.; VAN EMBDEN, J. D. A.; HARTSKEERL, R. A. Detection of Mycobacterium tuberculosis in clinical samples by using polymerase chain reaction and nonradioactive detection system. Journal of Clinical Microbiology, v. 30, n. 10, p. 2567-2575, 1992.

KOX, L. F. F.; RHIENTHONG, D.; MIRANDA, A. M.; UDOMSANTISUK, N.; ELLIS, K.; VAN LEEUWEN, J.; VAN HEUSDEN, S.; KUIJPER, S.; KOLK, A. H. J. A more reliable PCR for the detection of Mycobacterium tuberculosis in clinical samples. Journal of Clinical Microbiology, v. 32, n. 3, p. 672-678, 1994.

LIÉBANA, E.; ARANAZ, A. ; MATEOS, A. ; VILAFRANCA, M.; GOMEZ-MAMPASO, E.; TERCERO, J. C.; ALEMANY, J.; SUAREZ, G.; DOMINGO, M.; DOMINGUEZ, L. Simple and rapid detection of Mycobacterium tuberculosis complex organisms in bovine tissue samples by PCR. Journal of Clinical Microbiology, v. 33, n. 1, p. 33-36, 1995.

LIÉBANA, E.; ARANAZ, A.; FRANCIS, B.; COUSINS, D. Assessment of genetic markers for species differentiation within the Mycobacterium tuberculosis complex. Journal of Clinical Microbiology, v. 34, n. 4, p. 933-938, 1996.

MARTINS, M. C. Estudo crítico da utilização das técnicas de biologia molecular na detecção e identificação de micobactérias, em especial, M. tuberculosis. 2000. $111 \mathrm{f}$. Dissertação (Mestrado em Epidemiologia) - Faculdade de Saúde Pública, Universidade de São Paulo, São Paulo, 2000.

MISHRA, A.; SINGHAL, A.; CHAUHA, D. S.; KATOCH, V. M.; SRIVASTAVA, K.; THAKRAL, S. S.; BHARADWAJ, S. S.; SREENIVAS, V.; PRASAD, H. K. Direct detection and identification of Mycobacterium tuberculosis and Mycobacterium bovis in bovine samples by a novel nested PCR assay: correlation with conventional techniques. Journal of Clinical Microbiology, v. 43, n. 11, p. 5670-5678, 2005.

MONAGHAN, M. L.; DOHERTY, M. L.; COLLINS, J. D.; KAZDA, J. F.; QUINN, P. J. The tuberculin test. Veterinary Microbiology, v. 40, p. 111-124, 1994.

NOLTE, F. S.; METCHOCK, B.; MCGOWAN, J. E.; EDWARDS, A.; OKWUMABUA, O.; THURMOND, C.; MITCHELL, P. S.; PLIKAYTIS, B.; SHINNICK, T. Direct detection of Mycobacterium tuberculosis in sputum by polymerase chain reaction and DNA hybridization. Journal of Clinical Microbiology, v. 31, n. 7, p. 1777-1782, 1993.

OGUSKU, M. M.; SADAHIRO, A.; HIRATA, M. H.; HIRATA, R. D. C.; ZAITZ, C.; SALEM, J. I. PCR in the diagnosis of cutaneous tuberculosis. Brazilian Journal of Microbiology, v. 34, p. 165-170, 2003. 
PAO, C. C.; YEN, T. S. B.; YOU, J. B.; MAA, J. S.; FISS, E. H.; CHANG, C. H. Detection and identification of Mycobacterium tuberculosis by DNA amplification. Journal of Clinical Microbiology, v. 28, n. 9, p. 1877-1880, 1990.

PAN AMERICAN HEALTH ORGANIZATION. Health conditions in the Americas, 1990. Washington, D.C.: Pan American Health Organization, 1991. v. 1. (Scientific Publication, n. 524).

ROMERO, R. E.; GARZÓN, D. L.; MEJÍA, G. A.; MONROY, W.; PATARROYO, M. E.; MURILLO, L. A. Identification of Mycobacterium bovis in bovine clinical samples by PCR species-specific primers. Canadian Journal of Veterinary Research, v. 63, p. 101-106, 1999.

ROSALES RODRIGUEZ, C.A. Sistema de deteç̧ão de focos de tuberculose bovina no Estado de São Paulo utilizando métodos moleculares e epidemiológicos. 2005. $86 \mathrm{f}$. Tese (Doutorado em Medicina Veterinária) - Faculdade de Medicina Veterinária e Zootecnia, Universidade de São Paulo, São Paulo. 2005.

ROSSEN, L.; NORSKOV, P.; HOLMSTROM, K. e RASMUSSEN, O. F. Inhibition of PCR by components of food samples, microbial diagnostic assays and DNA-extraction solutions. International Journal of Food Microbiology, v. 17, p. 37-45, 1992.

ROXO, E. Avaliação da resposta imunoalérgica cutânea à tuberculina em bubalinos (Bubalus bubalis). 1996. 55 f. Tese. (Doutorado em Medicina Veterinária) - Faculdade de Medicina Veterinária e Zootecnia, Universidade de São Paulo, São Paulo, 1996.

SAKAMOTO, S. M. Tificação de Mycobacterium bovis por spoligotyping e por análise de número variável de repetições seriadas (VNTR). 2001. 47 f. Tese (Doutorado em Medicina Veterinária) - Faculdade de Medicina Veterinária e Zootecnia, Universidade de São Paulo, São Paulo, 2001.

SAMBROOK, J.; FRITCH, E.; MANIATIS, T. Gel electrophoresis of DNA. In: Molecular cloning: a laboratory manual. 2. ed. Cold Spring Harbor: Cold Spring Harbor Laboratory Press, 1989. p. 6.0-6.62.

SANTOS, A. R.; GOES FILHO, J. T.; NERY, J. A. C.; DUPPRE, N. C.; GALLO, M. E. N; SUFFYS, P. N.; DEGRAVE, W. M. Evaluation of PCR mediated DNA amplification in noninvasive biological specimens for subclinical detection of Mycobacterium leprae. FEMS Immunology and Medical Microbiology, v. 11, p. 113-120, 1995.

SOOLINGEN, D.; ZANDEN, A. G. M.; HAAS, P. E. W.; HERMANS, P. W. M.; KOEDAM, M. A.; TEPPEMA, K. S.; BRENNAN, P. J.; BESTRA, G. S. PORTAELS, F.; TOP, J.; SCHOULS, L. M.; EMBEDEN, J. D. A. A novel pathogenic taxon of the Mycobacterium 
tuberculosis complex, Canetti; characterization of an exceptional isolate from Africa. International Journal of Systematic Bacteriology., v. 47, p. 1236-1245, 1997.

SOOLINGEN, D.; HERMANS, P. W. M.; HAAS, P. E. W.; SOLL, D. R.; EMBDEN, J. D. A. Occurrence and stability of insertion sequences in Mycobacterium tuberculosis complex strains: evaluation of an insertion sequence-dependent DNA polymorphism as a tool in the Epidemiology of tuberculosis. Journal of Clinical Microbiology, v. 29, n. 11, p. 2578-2586, 1991.

SOOLINGEN, D.; ZANDEN, A. G. M.; HASS, P. E.W.; NOORDHOEK, G. T.; KIERS, A.; FOUDRAINE, N. A.; PORATELS, F.; KOLK, A. H. J.; DREMER, K.; EMBDEN, J. D. A. Diagnosis of Mycobacterium microti infections among humans by using novel genetic markers. Journal of Clinical Microbiology, v. 36, n. 7, p. 1840-1845, 1998.

STEELE, J. M. Regional and country status report/Introduction. In: THOEN, C. O.; STEELE, J. H. Mycobacterium bovis infection in animals and humans. Ames: Iowa State University Press, 1995. p. 1659-1672.

THIERRY, D.; BRISSON-NOËL, A.; VINCENT-LÉVY-FRÉBAULT, V.; NGUYEN, S.; GUESDON, J. L.; GICQUEL, B. Characterization of a Mycobacterium tuberculosis insertion sequence, IS6110, and its application in diagnosis. Journal of Clinical Microbiology, v. 28, n. 12, p. 2668-2673, 1990.

VANEECHOUTE, M.; ELDERE, J. The possibilities and limitations of nucleic acid amplification technology in diagnostic microbiology. Journal of Medical Microbiology, v. 46, p. 188-194, 2001.

WARDS, B. J.; COLLINS, D. M.; LISLE, G. W. Detection of Mycobacterium bovis in tissues by polymerase chain reaction. Veterinary Microbiology, v. 43, p. 2227-2240, 1995.

WILSON, I. G. Inhibition and facilitation of nucleic acid amplification. Applied and Environmental Microbiology, v. 63, n. 10, p. 3741-3751, 1997.

WRIGHT, P. A.; WYNFORD-THOMAS, D. The polymerase chain reaction: miracle or mirage? A critical review of its uses and limitations in diagnosis and research. Journal of Pathology, v. 162, p. 99-117, 1990.

YAJKO, D. M.; WAGNER, C.; TEVERE, J.; KOCAGOZ, T.; HADLEY, W. K.; CHAMBERS, H. F. Quantitative culture of Mycobacterium tuberculosis from clinical sputum specimens and dilution endpoint of its detection by the amplicor PCR assay. Journal of Clinical Microbiology, v. 33, n. 7, p. 1944-1947, 1995. 
YOUMANS, G. M. The morphology and metabolism of mycobacteria. In:

Tuberculosis. Philadelphia: WB.Saunders Company, 1979. p. 8-45.

ZANG, Q. Z.; ISHAQUE, M. Evaluation of methods for isolation of DNA from slowly and rapidly growing mycobacteria. International Journal of Leprosy, v. 65, n. 4, 1997.

ZANINI, M. S.; MOREIRA, E. C.; LOPES, M. T.; MOTA, P.; SALAS, C. E. Detection of Mycobacterium bovis in milk by polymerase chain reaction. Journal of Veterinary Medicine B, v. 45, p. 473-479, 1998.

ZANINI, M. S.; MOREIRA, E. C.; LOPES, M. T. P.; OLIVEIRA, R. S.; LEÃO, S. C.; FIORAVANTI, R. L.; ROXO, E.; ZUMÁRRAGA, M.; ROMANO, M. I.; CATALDI, A.; SALAS, C. E. Mycobacterium bovis: polymerase chain reaction identification in bovine lymphonode biopsies and genotyping in isolates from Southeast Brazil by spolygotyping and restriction fragment length polymorphism. Memórias do Institudo Oswaldo Cruz, v. 96, n. 6, p. 809-813, 2001.

ZUMÁRRAGA, M. J.; CICUTA, M. E.; MARTIN, C.; CATALDI, A.; ALITO, A.; IGI, F.; ROXO, E. SAKAMOTO, S.; ROMANO, M. I. Epidemiologia molecular de aislamientos de Mycobacterium bovis del Nordeste Argentino y e Brasil utilizando la técnica de spoligotyping. Comunicaciones Científicas y Tecnológicas, Universidade Nacional del Nordeste, Argentina, 1999. 4 p.

ZUMÁRRAGA, M. J.; PAOLICCHI, F.; GARBACCIO, S.; GIOFFRÉ, A.; CATALDI, A. Aplicación de la PCR en la detección de Mycobacterium bovis en muestras de tejido de terneros. Veterinaria Argentina, v. 28, n. 179, p. 668-676, 2001. 
ANEXO 
ANEXO A - Soluções utilizadas no protocolo de Boom et al. (1990):

TAMPÃO DE LISE

$120 \mathrm{~g}$ de isotiocianato de guanidina

$1 \mathrm{ml}$ de Triton $100 \mathrm{x}$

8,8 $\mathrm{ml}$ de EDTA 0,5M (pH 8,0)

111,2 ml de Tris- $\mathrm{HCl} \mathrm{0,1M} \mathrm{(pH} \mathrm{6,4)}$

\section{TAMPÃO DE LAVAGEM}

$120 \mathrm{~g}$ de isotiocianato de guanidina

100ml de Tris- $\mathrm{HCl} 0,1 \mathrm{M}$ (pH 6,4)

\section{SOLUÇÃO CARREADORA}

$1 \mathrm{~g}$ Diatomaceous earth

$5 \mathrm{ml}$ de água

$50 \mu \mathrm{l}$ de $\mathrm{HCl} 37 \%$

\section{TAMPÃO DE ELUIÇÃO}

$10 \mathrm{mM}$ Tris- $\mathrm{HCl}(\mathrm{pH} 7,5)$

1 mM EDTA 